\title{
The Effects of Conditional Cash Transfer Programmes on Adult Labour Supply: An Empirical Analysis Using a Time- Series-Cross-Section Sample of Brazilian Municipalities ${ }^{\star}$
}

\author{
- Miguel Nathan Foguel*
}

\author{
- Ricardo Paes de Barros**
}

\begin{abstract}
Resumo
Neste trabalho, estimamos os efeitos dos Programas Condicionais de Transferência de Renda (PCTR), no Brasil, sobre a oferta de trabalho de mulheres e homens adultos. Para tanto, utilizamos o painel de municípios que são continuamente cobertos pela Pesquisa Nacional por Amostra de Domicílios (PNAD/ IBGE) durante o período entre 2001 e 2005. Os efeitos dos PCTR brasileiros são estimados tanto sobre a taxa de participação quanto sobre o número médio de horas trabalhadas. Como a PNAD não investiga diretamente a participação das famílias em PCTR, utilizamos um procedimento indireto para identificar as famílias beneficiárias desses programas. Nossos resultados indicam que os efeitos de interesse não são significativos tanto do ponto de vista estatístico como em termos de magnitude.
\end{abstract}

\section{Palavras-Chave}

programas sociais, oferta de trabalho, dados de painel

\begin{abstract}
In this paper, we estimate the effects of the Conditional Cash Transfer (CCT) programmes in Brazil on the labour supply of adult males and females. We employ the panel of municipalities that are continuously investigated by the Pesquisa Nacional por Amostra de Domicílios (PNAD/IBGE) over the years 2001-2005. The effects of the Brazilian CCT programmes are estimated both on the participation rate and the mean number of hours worked. Since PNAD does not ask directly surveyed families about CCT programme participation, we use an indirect procedure to identify beneficiary families. Our results indicate that the effects of interest are not significant both on statistical grounds and in terms of magnitude.
\end{abstract}

\section{Keywords}

social programmes, labour supply, panel data

\section{JEL Classification}

$138, \mathrm{~J} 22, \mathrm{C} 33$

\footnotetext{
+ The authors would like to thank Sergei Soares, Reynaldo Fernandes, João Sabóia, Carlos Corseuil, Claudio Ferraz, Maurício Reis, Eustáquio Reis and various seminar participants for their useful comments. The usual disclaimer applies.

* Instituto de Pesquisa Econômica Aplicada (IPEA). E-mail: miguel.foguel@ipea.gov.br.

** Instituto de Pesquisa Econômica Aplicada (IPEA). E-mail: ricardo.barros@ipea.gov.br.

Contact address: Instituto de Pesquisa Econômica Aplicada (IPEA) - Av. Presidente Antônio Carlos, 51 - $14^{\circ}$ andar - Centro - Rio de Janeiro. CEP: 22020-010.

(Recebido em janeiro de 2009. Aceito para publicação em agosto de 2009).
} 


\section{Introduction}

In recent years, there has been a widespread diffusion of Conditional Cash Transfers (CCT) programmes in Latin America. As implied by their name, these programmes provide monetary grants to poor families conditional on the fulfilment of a set of requirements, such as keeping children at school and bringing them to regular visits to health clinics. In general, the stated objective of this type of programme is twofold. The first is alleviation of current poverty, a goal that is pursued through the regular payments of benefits to recipient families. The second goal, which is based on the programmes' conditionalities, seeks to foster human capital accumulation of children so as to reduce long-term structural poverty. By now, many scholars and policy makers see CCT programmes as a model of social safety nets for the developing world.

In trying to accomplish their objectives, CCT programmes may affect beneficiary families in many dimensions. These include the level and patterns of consumption, the health conditions of family members, investments in physical and human capital, and the labour supply of children and adults. In this paper, we focus on the effects of CCT programmes on the supply of labour of adults. Specifically, our objective is to measure CCTs' effects on the participation rate and number of hours worked by male and female adults in Brazil. Although the most relevant effects of CCTs are likely to pertain to their impacts on children, we believe investigating CCTs' impacts on adult labour supply is an important issue. Indeed, there is a general belief that CCT programmes produce the socially undesirable outcome of making beneficiary adults to work less. However, it has not been completely established neither on theoretical nor on empirical grounds that CCTs provoke this adverse effect.

There are many different empirical strategies that can be used to investigate the effects of CCT programmes on adult labour supply. Ideally, one would like to count on a social experiment to compare the labour supply behaviour of the randomly assigned treatment and control groups. However, this is not available for most countries where CCT programmes have been implemented, including Brazil. In this situation, non-experimental methods must be used. In general, studies that rely on these methods employ individual data to find a comparison group that resembles the treatment group had the latter not received the programme. Our empirical method is also non-experimental, but instead of searching for a single comparison group we exploit the time-series-cross-section variation from a large sample of Brazilian municipalities to assess the effects of interest. Specifically, based on micro-data from a national, cross-section household survey (the Pequisa Nacional por Amostra de Domicílios - PNAD), we calculate sample means at the municipal 
level for our outcome variables of interest (the participation rate and number of hours worked) and for a set of covariates, including a measure we develop for CCT programme participation. To obtain variation over time, we benefit from the fact that PNAD is annually fielded in the same set of municipalities between census years (only households are randomly sampled across years). Our sample period is 2001-2005.

To the best of our knowledge, this is the first study that uses aggregated data to assess the labour supply effects of CCT programmes. However, there are an increasing number of studies that have employed individual level data to investigate this issue. Parker and Skoufias (2000) use experimental microdata from PROGRESA to estimate the effect of the programme on the participation rate of male and female adults at different points in time for distinct age groups, categories of workers, and definitions of the eligibility criteria. Point estimates were mostly positive for males and negative for females. However, except for a small set of age groups and points in time, most estimates were not significant on statistical grounds. They then conclude that there is no evidence that PROGRESA affects the labour force participation of adults. Ferro and Nicollela (2007) use microdata from PNAD 2003, which contained two specific questions on CCT programme participation: one for whether families were signed-up for any of the existing programmes at the time of the survey, and another for whether they were already receiving the programmes' transfers. They utilise these two pieces of information to create a treatment group (those receiving the benefits) and a control group (those enrolled but still not receiving the benefits). The authors estimate the effects of the Brazilian CCT programmes on both the participation rate and number of hours worked by male and female adults in urban and rural areas. Their estimates of the programmes' effect on the participation rate are small in magnitude and statistically nil for both males and females in urban and rural areas. As for the estimates on hours worked, the results show a negative effect for males in urban and rural areas (but only statistically significant for the former area), a positive impact for urban women, and a negative effect for females in rural areas. Medeiros et al. (2007) use microdata from PNAD 2004 to estimate the effect of CCT programmes on the probability of being in the labour force for adult males or females. Results are obtained separately for heads of families and spouses who live in families below the 30th percentile of the per capita family income distribution. They find that labour market engagement does not seem to be affected by participation in the programmes for almost all groups considered (the exception is female heads, for whom the effect is negative). Cedeplar (2006 apud MEDEIROS et al., 2007) use a non-experimental household survey that was specifically fielded in 2005 to evaluate the effects of the Brazilian CCT programmes on e.g., education, health, nutrition, and labour market outcomes. In terms of labour supply, they find a positive effect of Brazilian 
CCTs on the participation rate of male and female adults. Using the 2004 version of PNAD, Tavares (2008) employs matching methods with different control groups to estimate the impact of CCTs on the labour supply of beneficiary Brazilian mothers. As in Ferro and Nicollela (2007), estimates are obtained for both the labour force participation and the number of hours worked. Regarding the former outcome, her results indicate a positive and statistically significant effect; as for the latter, the estimates change sign depending on the control group being used and tend not to be significant on statistical grounds.

This paper is organised as follows. In the next section we provide a description of the Federal CCT programmes that have been implemented in Brazil in the last decade. The third section is dedicated to describe the data we use, including the procedure we adopt to identify CCT beneficiaries. In section 4 , we briefly discuss how CCT programmes may affect the labour supply of adults. Since there are no aggregate models that connect the effects of CCT programmes on labour supply, we base our discussion on standard labour supply theory at the family level. Section 5 presents our empirical methodology, which is based on different linear regression models that are typically used in the panel data literature. Results are presented in section 6 and are obtained separately by gender for two distinct samples: one that includes all individuals, and another for those individuals in families below the median per capita family income of the municipalities they live in. In the last section we present the main conclusions.

\section{Description of Programmes}

Before October 2003, there existed five Federal CCT programmes in Brazil. The oldest was the Programa de Erradicação do Trabalho Infantil (PETI), which was launched in 1996, and whose aim was to eradicate child labour. It was targeted to families with children aged 7 to 15 years who were working (or at risk to work) in activities considered to be harmful for their health. The value of the programme's transfer was R $\$ 25$ (US\$37 PPP) per child in rural areas and R $\$ 40$ (US\$59 PPP) per child in urban areas. The programme's conditionalities required that children under 16 years of age did not work and maintained at least $75 \%$ school attendance.

Three programmes were created in 2001. The Federal Bolsa Escola programme had as its target population those families with children aged 6 to 15 years and whose per capita income was less than R $\$ 90$ (US $\$ 97$ PPP). Its transfer was R $\$ 15$ (US $\$ 16$ PPP) per child, up to a maximum of three children, that is, with an upper limit of $\mathrm{R} \$ 45$. The programme's conditionality stipulated that participant children had to attend school at least $85 \%$ of the school year. The Bolsa Alimentação programme 
had as its goal the reduction of infant mortality in families whose per capita income was below half the value of the prevailing minimum wage. The transfer was $\mathrm{R} \$ 15$ (US\$16 PPP) per child under 6 years old, or pregnant woman, cumulative up to $\mathrm{R} \$ 45$. The conditionalities involved immunisation of young children and regular visits to health centres for pregnant and breast-feeding women. The last programme launched in 2001 was the so-called Auxílio-Gás. Targeted to families whose per capita income was lower than R $\$ 90$ (US $\$ 97$ PPP), it provided R $\$ 7.50$ (US $\$ 8$ PPP) as a subsidy to buy cooking gas. Auxílio-Gás only required that beneficiary families were registered in the so-called Federal government's Cadastro Único (Unified Register).

In the beginning of 2003, the Cartão Alimentação programme was created for families with per capita income below half the minimum wage. It transferred $\mathrm{R} \$ 50$ (US\$54) to beneficiary families with the aim to reduce hunger to very low levels. The programme's grant had to be spent on food only.

In October 2003, the Federal government launched the Bolsa Família programme. It unified all previous CCT programmes, which were run by different agencies, had their separate information systems, and their own financing. Its target population consists of two groups of families. Families in extreme poverty (per capita income below $\mathrm{R} \$ 50$ (US $\$ 42 \mathrm{PPP}$ )) receive a fixed transfer of $\mathrm{R} \backslash \$ 50$. If there are children under 15 years old or pregnant women, these families also get R $\$ 15$ (US\$13 PPP) per child or pregnant woman, up to a maximum of $\mathrm{R} \$ 45$. The maximum amount is therefore $\mathrm{R} \$ 95$ for this group. The second group consists of families in moderate poverty (per capita income between R $\$ 50$ (US\$42 PPP) and R \$100 (US\$85 PPP)). Families in this group only receive the benefits if there are children less than 15 years of age or pregnant women in the household. The transfer is the same as the variable part of the previous group, i.e. $\mathrm{R} \$ 15$ per child or pregnant woman, also cumulative up to $\mathrm{R} \$ 45$. For this group, the maximum amount is $\mathrm{R} \$ 45$. In terms of conditionalities, the programme requires $85 \%$ school attendance for school-age children, immunisation of children under 6 years old, and regular medical checkups for pregnant and breast-feeding women.

\section{Data}

All data we use in the empirical analysis come from the Pesquisa Nacional por Amostra de Domicílios - PNAD (National Household Survey). PNAD is fielded on a yearly basis (usually in October) and gathers information on demographic and socio-economic characteristics of every member of the household. We use data for the period 2001 to 2005 . 
PNAD is a cross-section survey, so we cannot follow households/individuals over time. However, its sampling scheme allows the construction of a time-series of cross-sections of municipalities in Brazil. This is because the municipalities that enter the sample are selected at the beginning of every decade and, though sampled households change across years, the same set of municipalities is kept constant within that decade. We take advantage of this feature of the survey to construct our panel of municipalities.

For the current decade, PNAD's sample contains 817 municipalities that can be partitioned in three groups: 139 are situated in metropolitan areas, 134 are not in metropolitan areas but have large populations, and 544 are smaller municipalities. Because the number of individual observations for some municipalities was small, we decided to join municipalities with less than 100 observations in one of these groups to a municipality that belonged to the same group in the same state of the country. Altogether there were 11 municipalities in this situation, so we work with 806 municipalities that are followed over five years (total of 4030 time-seriescross-section observations). Table 1 displays the average, the minimum and the maximum number of individual observations across this set of municipalities over the sample period.

Table 1 - Number of Individual Observations in PNAD's Municipalities by Year

\begin{tabular}{lccc}
\hline Year & Average & Minimum & Maximum \\
\hline 2001 & 458 & 107 & 11221 \\
2002 & 466 & 106 & 12050 \\
2003 & 465 & 104 & 11782 \\
2004 & 470 & 103 & 11520 \\
2005 & 483 & 103 & 12338 \\
\hline
\end{tabular}

Source: Based on microdata from the PNADs.

All variables we use in the regression analysis are mean sample values at the municipal level. PNAD's sample design does not guarantee that municipal samples are representative of their underlying parent populations. ${ }^{1}$ In particular, there may appear problems of inconsistency and lower precision for inference about the local population parameter values (e.g. the mean of a municipal variable). For regression purposes, like ours, these problems create measurement error in regression variables (specially covariates), an issue that tend to bias the estimation of regression para-

1 See Silva et al. (2002) for a description of PNAD sample design. 
meters. Fortunately, there are some methods that have been developed to remedy that, with the instrumental variable procedure, which is applied here, being one of the most widely used. ${ }^{2}$ In section 5 we discuss how we implement this method.

The PNADs' data sets contain sampling weights for individual observations. We use these weights to compute descriptive statistics for the whole country. We also use these weights to compute the population size in each municipality for each year of our data. The total population of each municipality across the years is used as a fixed weight in all regressions we run.

Before presenting descriptive statistics of the variables used in the regression analysis, there is one important issue related to the way we identify individuals that receive CCT programmes in PNAD. We discuss it in the following subsection.

\subsection{Identifying Beneficiaries of CCT Programmes}

In the main questionnaire of PNAD, there are no specific questions that explicitly ask whether interviewed households receive CCT programmes. In the lack of such direct information, we therefore created a procedure that tries to indirectly identify the beneficiaries of these programmes across the years.

PNAD's main questionnaire contains a set of questions in which the values of the different income sources a household may have are recorded. One of these questions refers to the value of household income that is obtained from both financial assets (e.g. interests and stock market shares) and transfers from social programmes. Note that income from both sources is reported together. However, one should expect that those households that derive income from financial assets tend not to receive benefits from social programmes. Based on this hypothesis, we use the information provided in this specific question to identify CCT beneficiaries. Specifically, our procedure makes use of the typical values of the benefits of CCT programmes to identify households that are (potentially) beneficiaries of these programmes. Table 2 presents the values typically transferred by each CCT programme. ${ }^{3}$ Since a household may receive transfers from more than one of these programmes, our procedure also uses the combination of these values to identify the beneficiary households. All values that were not equal to the typical values and

2 See Fuller (1987) for a general presentation of other methods to solve measurement error problems.

3 It should be noted that in practice we use the values of $\mathrm{R} \backslash \$ 7$ or $\mathrm{R} \backslash \$ 8$ to capture the Auxilio-Gás programme. This is due to the fact that monetary values with decimal digits are not captured by PNAD. 
their combinations were treated as income from financial assets or from non-CCT programmes. $^{4}$

\section{Table 2 - Typical Values of Benefits Transferred by CCT Programme}

\begin{tabular}{ll}
\hline Programme & \multicolumn{1}{c}{ Benefit Value (R\$) } \\
\hline PETI (per child) & 25 (rural), 40 (urban) \\
Bolsa Escola & $15,30,45$ \\
Bolsa Alimentação & $15,30,45$ \\
Auxílio-Gás & 7.50 \\
Cartão Alimentação & 50 \\
Bolsa Família & $15,30,45,50,65,80,90$ \\
\hline
\end{tabular}

Source: Barros et al. (2007, Table 6).

To validate our procedure, we take advantage of the fact that the 2004 version of PNAD included a special questionnaire that directly asked whether the household was participating in the Federal CCT programmes. Using the information provided by this special questionnaire as a reference, we then check if our procedure is consistent. Specifically, we calculate the proportion of recipient and non-recipient individuals of CCT programmes according to the special questionnaire and to our procedure. The results are presented in Table 3.

Table 3 - Proportion of CCT Beneficiaries: Comparison between the Special Questionnaire and the Procedure of Typical Values - (\%)

\begin{tabular}{llcc}
\hline & & \multicolumn{2}{c}{ Special Questionnaire } \\
\cline { 3 - 4 } & & Recipient & Non-recipient \\
\hline \multirow{3}{*}{ Typical Values } & Recipient & 18.4 & 2.2 \\
& & & 77.7 \\
\hline
\end{tabular}

Source: Based on microdata from PNAD 2004.

There are four main results that can be extracted from Table 3. Firstly, around $96 \%$ $(18.4+77.7)$ of individuals were identically classified by both criteria. Secondly, around $8 \%(1.7 /(1.7+18.4))$ of those individuals identified as recipients by the spe-

4 We also impose a restriction that the typical values and their combinations should be less than $\mathrm{R} \$ 175$. 
cial questionnaire were not classified as such by our procedure. In other words, approximately 92\% of recipients were correctly identified by our proposed procedure. Thirdly, around 3\% (2.2/(2.2+77.7)) of those classified as beneficiaries by our procedure were not identified by the special questionnaire. Finally, Table 3 also reveals that programme participation is only slightly overestimated by our procedure. Indeed, while our procedure classifies $20.6 \%(18.4+2.2)$ of the population as beneficiaries, this proportion is $20.1 \%(18.4+1.7)$ according to the special questionnaire.

Figures 1 and 2 present complementary evidence on the accuracy of our procedure. Still based on PNAD 2004, Figure 1 presents the proportion of individuals in each percentile of the per capita family income distribution that are recipients of CCT programmes. One of the curves in this Figure is based on our procedure, while the other is calculated from the information of the special questionnaire. ${ }^{5}$ Apart from revealing that the Brazilian CCT programmes were reasonably well targeted to the poor, Figure 1 evinces that our procedure seems to consistently classify the recipients of CCT programmes along almost the entire income distribution. As expected, our procedure tends to slightly overestimate programmes' participation for richer individuals.

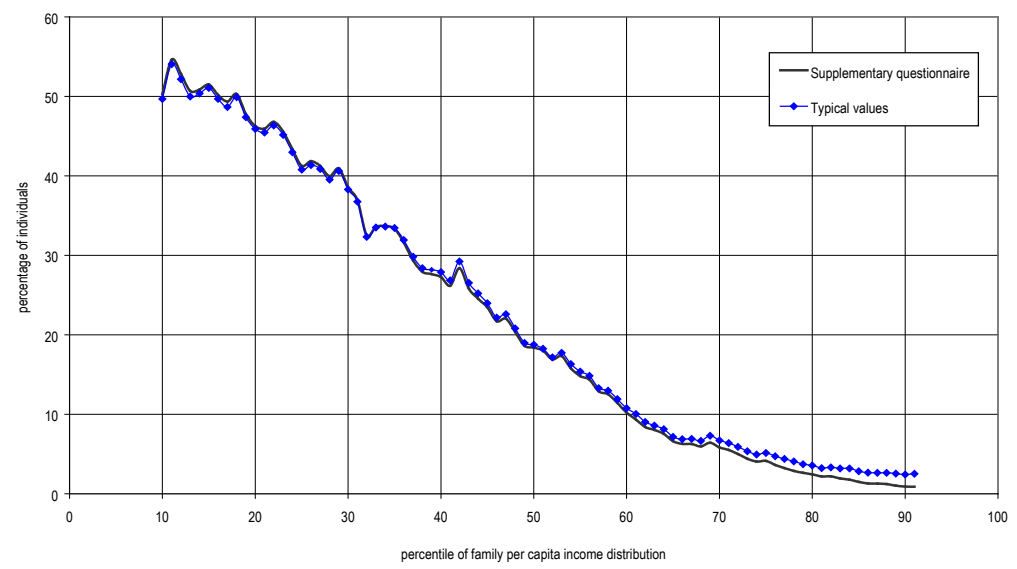

Source: Based on microdata from PNAD 2004.

Figure 1 - Percentage of CCT Beneficiaries across Percentiles of the Income Distribution: Special Questionnaire and Method of Typical Values

5 In order to smooth these curves, they are depicted as a moving average of ten percentiles. For example, the point corresponding to the $10^{\text {th }}$ percentile represents the average of the $1^{\text {st }}$ to the $10^{\text {th }}$ percentiles. 
As a final validation test of our procedure, we exploit two facts that are related to the historical evolution of CCT programmes in Brazil. The first is that all CCT programmes but one (namely PETI) started operating after 2001 (see Table 2). Hence, if our procedure is correct we should expect to detect fewer CCT individuals before that year. The second fact is that the coverage of CCT programmes progressively increased since 2001, so our procedure should be capable to detect this movement as well. Figure 2, which is solely based on our procedure, presents the evolution of the percentage of individuals along the per capita family income distribution for a set of years since 1999. ${ }^{6},{ }^{7}$ As it can be seen from this figure, the two historical facts previously mentioned seem to be reasonably well captured by our proposed method: (1) the line corresponding to 1999 is almost flat; and (2) the lines corresponding to the years after 1999 are basically overlapped.

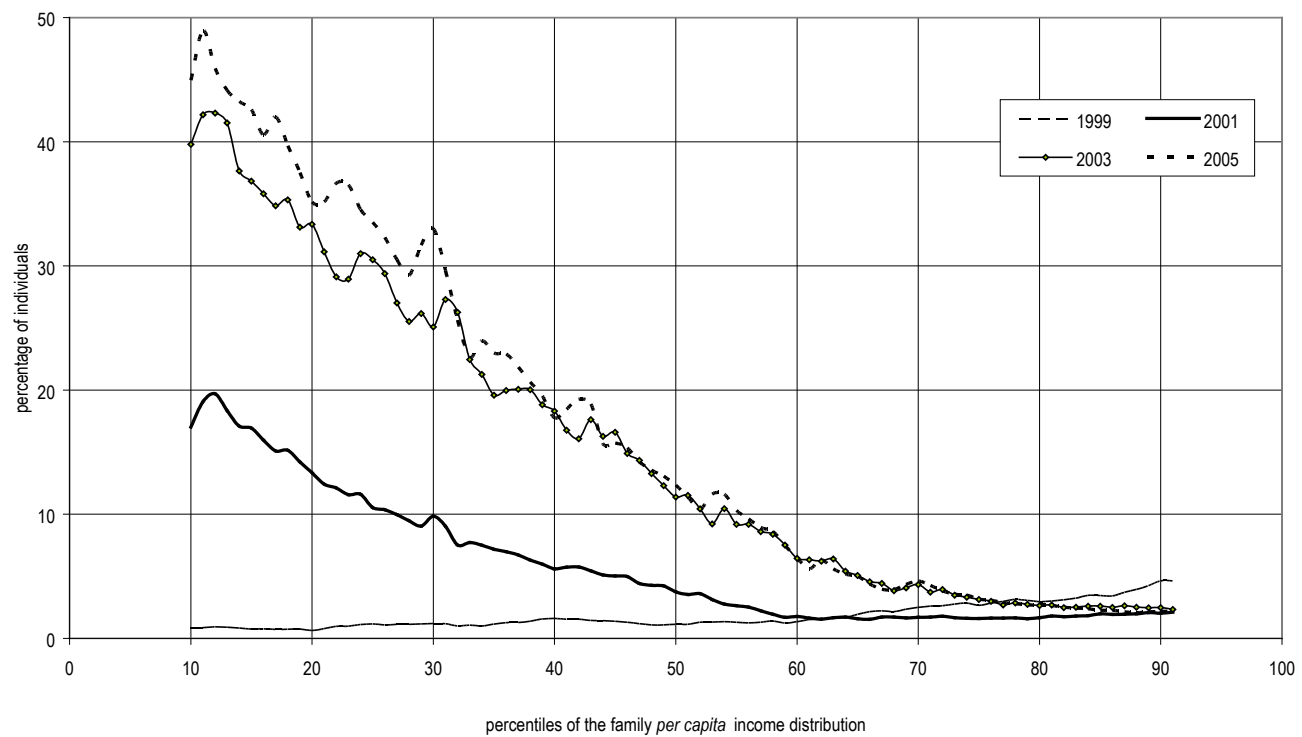

Source: Based on microdata from PNAD.

\section{Figure 2 - Percentage of CCT Beneficiaries across Percentiles of the Income Distribution: Method of Typical Values - Selected Years}

Overall, we believe that the evidence presented in this subsection indicates that our proposed procedure is sufficiently accurate to measure CCT programme participation over time. Thus, in our regression analysis, the variable that we use to measure

6 The PNAD questionnaire of 1999 is the same as that used in the following years.

7 As in Figure 1, the lines depicted in Figure 2 are also moving averages of ten percentiles. 
programme participation is based on this procedure. Specifically, in the regressions we use the proportion of beneficiary individuals at the municipal level. ${ }^{8}$

\subsection{Descriptive Statistics}

As the labour supply effects of CCT programmes may be different for males and females, our empirical analysis is implemented separately by gender group. In addition, since the effects of interest may also vary across the different parts of the income distribution, results are obtained separately for the overall sample of each sex and for the samples of males and females from families below the median per capita family income of the municipality they live in (henceforth called below-median samples). ${ }^{9}$

The sample mean and standard deviation of the variables used in our regression analysis are presented in Table 4. Columns (2) and (3) display these statistics for the overall samples of females and males respectively, while columns (4) and (5) contain the estimates respectively for the below-median samples of females and males. Statistics are presented for all years combined (2001-2005). Almost all estimates are calculated for individuals of each gender group above the age of 15 years. The exceptions are: (1) the proportion of children under 14 years old, for which there is no distinction between the sexes; (2) the proportion of beneficiaries of CCT programmes, which includes individuals of all ages and genders; and (3) the unemployment rate, which is calculated for individuals older than 15 years of both sexes together.

The first two rows of Table 4 display the estimates of the two response variables used in the regression analysis: the labour market participation rate (Row (1)) and the mean number of hours worked during the reference week of the survey (Row (2)). ${ }^{10}$ On average, women have lower participation rates and work fewer hours than men. This is observed for both the overall and the below-median samples. Also noticeable is that the participation rate and hours worked of poorer women tend to be smaller than those of the overall female sample. Interestingly, this is only observed for the number of hours worked in the case of males.

8 One may raise the question that we are also including recipient rich families in our measure of programme participation. Thus, we also calculated programme participation excluding all families that were below the average (over the years) $75^{\text {th }}$ and $90^{\text {th }}$ percentiles of the family per capita income. At the municipal level, the correlation between our programme participation variable and the measure based on the $75^{\text {th }}\left(90^{\text {th }}\right)$ percentile is around $0,98(0,99)$.

9 The reason for establishing the threshold at the median is that the sample size for some municipalities is not very large.

10 According to the concepts used in PNAD, an individual is considered employed if he/she works at least one hour in the reference week of the survey; an individual is considered unemployed if he/she did not work during the reference week but searched for a job in that week. In the calculation of the mean number of hours worked we included all jobs an individual may have and incorporated all individuals with zero hours. 
Table 4 - Descriptive Statistics: Mean of Variables for All Years (2001-2005)

\begin{tabular}{|c|c|c|c|c|}
\hline \multirow{3}{*}{ Variables } & \multicolumn{2}{|c|}{ Overall Sample } & \multicolumn{2}{|c|}{ Below-Median Sample } \\
\hline & Females & Males & Females & Males \\
\hline & $(2)$ & (3) & $(4)$ & $(5)$ \\
\hline \multirow[t]{2}{*}{ 1. Participation Rate } & 55.8 & 81.0 & 52.6 & 80.7 \\
\hline & $(9.1)$ & $(6.0)$ & $(11.8)$ & (7.6) \\
\hline \multirow[t]{2}{*}{ 2. Hours Worked } & 17.7 & 33.9 & 14.5 & 31.9 \\
\hline & (3.7) & $(4.4)$ & $(4.3)$ & $(5.4)$ \\
\hline \multirow[t]{2}{*}{ 3. Proportion of Beneficiaries } & 13.6 & 13.6 & 19.4 & 19.4 \\
\hline & $(16.0)$ & $(16.0)$ & (22.1) & (22.1) \\
\hline \multirow[t]{2}{*}{ 4. Labour Earnings } & 194.0 & 464.3 & 31.8 & 85.3 \\
\hline & (123.3) & $(253.5)$ & $(20.1)$ & $(39.9)$ \\
\hline \multirow[t]{2}{*}{ 5. Non-Labour Earnings } & 91.2 & 102.4 & 14.4 & 12.4 \\
\hline & $(56.7)$ & $(74.1)$ & (8.6) & $(9.5)$ \\
\hline \multirow[t]{2}{*}{ 6. Unemployment Rate } & 9.5 & 9.5 & 15.1 & 15.1 \\
\hline & $(5.4)$ & $(5.4)$ & (8.9) & $(8.9)$ \\
\hline \multirow[t]{2}{*}{ 7. Proportion of Children Under 14} & 27.5 & 27.5 & 36.4 & 36.4 \\
\hline & $(5.2)$ & $(5.2)$ & (6.5) & $(6.5)$ \\
\hline \multirow[t]{2}{*}{ 8. Age } & 38.7 & 37.4 & 35.5 & 35.0 \\
\hline & $(2.7)$ & (2.3) & (3.0) & (2.6) \\
\hline \multirow[t]{2}{*}{ 9. Schooling } & 6.7 & 6.5 & 5.4 & 5.1 \\
\hline & $(1.6)$ & $(1.9)$ & (1.3) & $(1.5)$ \\
\hline \multirow[t]{2}{*}{ 10. Proportion of Married } & 52.0 & 56.0 & 53.2 & 59.0 \\
\hline & $(7.3)$ & $(5.7)$ & $(9.3)$ & $(7.7)$ \\
\hline \multirow[t]{2}{*}{ 11. Proportion of Whites } & 54.0 & 51.8 & 45.9 & 44.3 \\
\hline & $(24.1)$ & $(24.3)$ & $(24.2)$ & $(24.2)$ \\
\hline \multirow[t]{2}{*}{ 12. Proportion of Urban Population } & 85.3 & 83.7 & 82.1 & 80.5 \\
\hline & (21.3) & $(22.8)$ & $(24.5)$ & $(25.9)$ \\
\hline \multirow[t]{2}{*}{ 13. Proportion in Adm. Occupations } & 11.6 & 6.2 & 6.3 & 4.2 \\
\hline & $(6.6)$ & $(4.0)$ & $(6.1)$ & (3.9) \\
\hline \multirow[t]{2}{*}{ 14. Proportion in Service Occupations } & 31.0 & 11.9 & 44.5 & 14.1 \\
\hline & $(10.9)$ & $(5.8)$ & $(18.1)$ & $(9.1)$ \\
\hline \multirow[t]{2}{*}{ 15. Proportion in Comm. Occupations } & 12.1 & 9.1 & 11.4 & 8.9 \\
\hline & (5.8) & (4.5) & (8.0) & $(6.0)$ \\
\hline 16. Proportion in Other Occupations & 45.2 & 72.7 & 37.8 & 72.8 \\
\hline
\end{tabular}

Notes: Based on microdata from PNAD. The below-median samples (columns (4) and (5)) refer to individuals whose per capita family income is below the median family per capita income of their respective municipalities. All variables are mean sample values weighted by the sampling weights provided by PNAD. Standard deviations are in parentheses. Rows (4) and (5) are measured in R\$ of September 2005 (deflator: Índice de Preços ao Consumidor Amplo IPCA/ IBGE) - Consumer Price Index). 
Row (3) displays the estimates for our variable of interest: the proportion of individuals that received benefits of CCT programmes. These estimates are based on the procedure described in subsection 3.1. As it can be seen, on average, around 14\% of the population in all years of our sample was beneficiaries of CCT programmes. This figure increases to around 19\% of the population that live in families whose per capita income falls below the median family per capita income of their respective municipalities.

Rows (4) and (5) shows the estimates of mean labour and non-labour income respectively $^{11}$ Labour earnings of women is substantially lower, on average, than that of men (ratio of around 0.43 for the overall sample, and approximately 0.38 for the below-median sample). Interestingly, this gap is not so high in terms of non-labour income. In fact, women in the below-median sample seem to get slightly more than men in this part of the distribution.

Row (6) shows that the unemployment rate of females is substantially higher than that of males for both samples we use. Also noticeable is that the incidence of unemployment is much higher for poorer males and females.

Rows (7) shows that children under 14 years old represent around 28\% of the overall population and approximately $36 \%$ of the population below the median per capita income. Rows (8) and (9) show that women are slightly older and more educated than men. This is observed for both types of samples we are working with. Row (10) indicates that a lower proportion of women are married as compared to men. This difference is due to the larger size of the female population. As shown in Row (11), the proportion of white females is higher than that of males for the overall population, but this difference is smaller for those below median per capita income. Row (12) shows that the proportion of women living in urban areas is higher than that of men for both types of samples we are considering.

Rows (13) to (16) present the occupational composition for females and males. As it can be seen, the proportion of females in the first three categories (specially in service occupations) is higher than that of males. ${ }^{12}$

11 The measure of non-labour income does not include the value of transfers of CCT programmes. It includes the values of all other types of transfers available in the survey questionnaire such as pensions, rents, private transfers, capital income and benefits received from non-CCT programmes. These last two components correspond to all non-typical values (and their combinations) of our procedure to identify beneficiaries of CCT programmes (see subsection 3.1).

12 Due to a change in the occupational codes used in PNAD from 2002 on, we were only able to construct four different occupational categories that seemed compatible over time: administrative, service, commercial, and others. Because this last category includes the manufacturing industry, most males fall in that category. 


\section{Some Theoretical Considerations}

We are interested in the effects of CCT programmes on the labour supply of adults. Though our estimation of these effects is based on aggregate data, labour supply models at the individual/family level can provide useful insights about our effects of interest. ${ }^{13}$ In what follows, we use the reasoning of simple, static models of labour supply at the micro level.

In a standard model of individual labour supply, the effect of programmes' transfers constitutes a pure income effect: the extra income from programmes' grants allows individuals to afford more of all goods. According to theory, the income effect should increase the demand for all normal goods, including both consumption and leisure (assuming the latter is a normal good). Hence, if adults allocate their time only between work and leisure, the standard individual model predicts that the effect of CCT programmes is unambiguously negative on the labour supply of adults.

However, given that CCT programmes are targeted to household units and impose conditionalities that restrict the time use of (some of) its members, a labour supply model at the family level seems more appropriate than the individual model to enhance the understanding of our effects of interest. Indeed, in family models, the decisions on the supply of labour of each household member take into account the restrictions on and the inter-dependencies between the time allocation of all household members.

Because programme grants are conditioned on children's school attendance, the family model would predict that the shadow price (or relative value) of school rises, whereas the relative value of all other activities declines (say, work and leisure). This should lead to an increase in time allocated to school and a decrease in time devoted to all other activities together. In principle, it is unclear what the new composition of time dedicated these other activities will be (RAVALLION; WODON, 2000). For instance, it is possible that there is no change in child labour, so the increase in schooling time comes at the expense of a reduction in children's leisure. However, if there is a decline in the time children spend working, then there will be less available labour within the household. ${ }^{14}$ In that case, the relative price of labour inside the household tends to rise, which should lead to an increase in the

13 The extensive theoretical literature on labour supply is fairly well developed for both the individual and family units of analysis. However, the literature on more aggregate levels (e.g. municipalities, states, or countries) is scarce. See Killingsworth (1983) for a survey of first-generation models of labour supply, and Blundell and Macurdy (1999) for a review of more recent models.

14 Assuming that education and leisure are normal goods, the pure income effect from the programmes' grants would produce a reduction in child work as well. 
labour supply of adults. Thus, given that the income effect operates in the other direction, the total effect of CCT programmes on adult labour supply becomes ambiguous. $^{15}$

\section{Methodology}

We use various linear regression models to investigate the effect of CCT programmes on adult labour supply. We use a time series of cross-sections of 806 Brazilian municipalities that are followed over five years. This panel of municipalities is constructed from microdata of the 2001-2005 versions of PNAD (see section 3).

The effect of interest is assessed on two different variables: the participation rate and number of hours worked. The response variables and the covariates are described in section 3. Results are obtained separately by gender group and for two types of samples: one in which all individuals of each sex are used to construct the sample means (overall sample), and another in which the sample means of the sexes are calculated only for individuals below the median per capita family income of their respective municipalities (below-median sample). It is important to point out that the use of sample means may create measurement error problems, an issue that is tackled through the application of instrumental variables methods. ${ }^{16}$

Consider the following equation for municipality $j=1, \ldots, J$ at time period $t=1, \ldots, T$ :

$$
y_{j t}=\alpha+p_{j \tau} \gamma+x_{1 j t}^{\prime} \beta_{1}+x_{2 j}^{\prime} \beta_{2}+\eta_{j}+u_{j t}
$$

where y represents the response variable, $\mathrm{p}$ measures the proportion of individuals who are CCT beneficiaries, $\left(x_{1}, x_{2}\right)$ are vectors of time-variant and time-invariant control variables respectively, $\eta$ denotes unobserved municipality-specific effects, and $u$ is a mean zero disturbance term that is assumed to be uncorrelated across municipalities and time periods but whose variance may be clustered at the municipal level. The parameter $\alpha$ is an intercept, $\gamma$ is our parameter of interest, and $\left(\beta_{1}, \beta_{2}\right)$ are conformable vectors of parameters respectively associated with the control variables in $\left(x_{1}, x_{2}\right)$.

15 It should be pointed out that CCT eligibility criteria could also affect labour supply decisions within the household. Indeed, for CCT programmes that include periodic checks on family income, it is possible that (some) adults choose to work less (or not to work at all) so as to meet the income eligibility criterion of programmes. Another point to be raised is that compliance with the programmes' conditionalities may also affect the allocation of time within the family. For instance, complying with periodic clinic visits and school attendance of children may decrease the labour supply of some family members, especially women.

16 Another method to tackle error-in-variables problems in the context of time series of crosssections has been proposed by Deaton (1985). See also Fuller (1987) for a general approach to measurement error models. 
In total we estimate five different models. The first is simply pooled OLS. The second is the random effects model, which differs from pooled OLS in that it explicitly recognises the presence of municipality-specific effects, but assumes that they are uncorrelated with all covariates. This last assumption is relaxed in the fixed effect model, which is our third model. ${ }^{17}$ This model can be estimated through various methods, the most common of them being the within-groups transformation. Applied to equation 2 this transformation produces:

$$
\tilde{y}_{j t}=\tilde{p}_{j} \gamma+\tilde{x}_{1 j}^{\prime} \beta_{1}+\tilde{u}_{j}
$$

where the tilde notation denotes: $\tilde{\omega}_{j t}=\omega_{j t}-\bar{\omega}$, with $\bar{\omega}=T^{-1} \sum_{t=1}^{T} \omega_{j t}$. Notice that all time-invariant elements of equation 1 are swept out by the within-groups transformation, including the municipality-specific effects, $\eta_{\mathrm{j}}$. In a small-T setting as ours, the fixed effects estimator of $\gamma$ and $\beta_{1}$ is consistent as long as there is strict exogeneity. ${ }^{18}$

Another common method used in the panel data literature is the first-differences transformation. Denoting $\Delta \omega_{j t}=\omega_{\mathrm{jt}}-\omega_{j t-1}$, equation 1 can then be expressed in firstdifferences as:

$$
\Delta y_{j t}=\Delta p_{j t} \gamma+\Delta x_{1 j t}^{\prime} \beta_{1}+\Delta u_{j t}
$$

Note that because of the first difference transformation we loose one time period, so now $t=2, \ldots, T$. Note too that the first-difference transformation also sweeps out all time-invariant elements of equation 1 . Our fourth and fifth models are based on equation 3. The fourth model simply estimates that equation under the assumption that there is strict exogeneity (see footnote 18). The fifth model relaxes strict exogeneity, allowing for the presence of correlation between the error term and the covariates. ${ }^{19}$ Within our context, this type of correlation (endogeneity) may arise from two basic sources. The first has to do with measurement issues. As discussed in section 3, since we measure our variables (in particular the regression covariates) at the municipal level, error-in-variable problems are likely to be present in our setting. The second is not related to measurement issues, but to more substantial (economic) factors. For instance, if there are relevant omitted variables in equation 1 , it is likely that the error term will be correlated with the included covariates.

17 We report the usual Hausman test to assess the appropriateness of the random effects specification.

18 That is: $E\left[u_{j s} \mid Z_{j t}\right.$ for all $j$, and for all $s$ and $t$, where $Z_{j t}=\left(p_{j t}, x_{1 j t}, x_{2 j}\right)$.

19 More formally, it assumes that for all $j: E\left[u_{j s} \mid Z_{j t}\right]=0$ if $\mathrm{s}>t$ and $E\left[u_{j s} \mid Z_{j t}\right] \neq 0$ if $s \leq t$, where $Z_{j t}=\left(p_{j t}, x_{1 j t}, x_{2 j}\right)$. Note that this assumption allows for contemporaneous correlation between the error term and the covariates. 
A typical approach to deal with the presence of endogeneity is the use of instrumental variables. The main requirements for instruments to be valid are that they are correlated with the endogenous covariates and at the same time orthogonal to the error term in the equation. Hence, given our assumptions, valid instruments for $\left(\Delta p_{j t}, \Delta x_{1 j t}\right)$ are $\left(p_{j, t-2}, \ldots, p_{j 1} ; x_{1 j, t-2}, \ldots, x_{1 j 1}\right)$. Note that the use of lagged instruments at time period $\mathrm{t}-2$ implies that the fifth model is estimated for $t=3, \ldots, \mathrm{T}$. Since $\mathrm{T}=5$, our model is over-identified, so we can apply the Sargan/Hansen test of overidentifying restrictions. The estimation method of the fifth model is the so-called two-step GMM, as proposed by Arellano and Bond (1991). ${ }^{20}$

All models we estimate include year dummies. The standard errors of the models' coefficients are estimated through the usual sandwich-type robust/clustered (at the municipal level) method. ${ }^{21}$ The municipal population summed over the years that are used in the corresponding models weights regressions. F-tests for the joint significance of the models' coefficients are reported in the tables containing the regression estimates.

\section{Results}

We first present results for the participation rate and then for hours worked. For each sex, overall sample results are followed by below-median sample results.

\subsection{Participation Rate}

\subsubsection{Females}

Regression results for the participation rate of all females are presented in Table 5 . The coefficient of interest is the one corresponding to the variable proportion of beneficiaries. As this table shows, all point estimates of this coefficient are positive, though they are statistically significant only for the OLS and the random effects models. The Hausman test largely rejects the hypothesis that the random-effects specification is adequate. Indeed, as the following Tables will show, this hypothesis is strongly rejected by the Hausman test for both sexes, samples, and response variables we use. The Hansen test of over-identifying restrictions does not reject the null for the validity of the instruments used in the GMM model. This will also be observed in most of the following tables.

20 It has been found in the panel data literature that the standard errors of the two-step GMM may be inaccurately estimated in finite samples. To correct for that we apply the method put forward by Windmeijer (2005).

21 It is worth noticing that this method deals with heteroscedasticity problems that are likely to be produced from the calculation of sample means at the municipal level in our data. 
Table 5 - Effect of CCT Programmes on the Participation Rate of Females: Overall Sample

\begin{tabular}{|c|c|c|c|c|c|}
\hline Covariates & $\begin{array}{l}\text { OLS } \\
\text { (2) }\end{array}$ & $\begin{array}{c}\text { Random } \\
\text { Effects } \\
\text { (3) }\end{array}$ & $\begin{array}{c}\text { Fixed } \\
\text { Effects } \\
(4)\end{array}$ & $\begin{array}{c}\text { First } \\
\text { Difference } \\
\text { (5) }\end{array}$ & $\begin{array}{c}\text { GMM } \\
(6)\end{array}$ \\
\hline Proportion of beneficiaries & $\begin{array}{l}0.0604^{* * *} \\
(0.0224)\end{array}$ & $\begin{array}{l}0.0563^{\star * *} \\
(0.0136)\end{array}$ & $\begin{array}{c}0.0145 \\
(0.0165)\end{array}$ & $\begin{array}{c}0.0066 \\
(0.0160)\end{array}$ & $\begin{array}{c}0.0438 \\
(0.0629)\end{array}$ \\
\hline Labour income $(1 / 10)$ & $\begin{array}{l}0.0037^{\star * *} \\
(0.0005)\end{array}$ & $\begin{array}{l}0.0049^{* * *} \\
(0.0003)\end{array}$ & $\begin{array}{l}0.0047^{\star * *} \\
(0.0004)\end{array}$ & $\begin{array}{l}0.0026^{* * *} \\
(0.0003)\end{array}$ & $\begin{array}{c}0.0009 \\
(0.0021)\end{array}$ \\
\hline Non-labour income $(1 / 10)$ & $\begin{array}{l}-0.0034^{* * *} \\
(0.0006)\end{array}$ & $\begin{array}{l}-0.0028^{\star * *} \\
(0.0004)\end{array}$ & $\begin{array}{l}-0.0016^{* * *} \\
(0.0005)\end{array}$ & $\begin{array}{l}-0.0009^{* *} \\
(0.0004)\end{array}$ & $\begin{array}{l}-0.0027 \\
(0.0032)\end{array}$ \\
\hline Unemployment rate & $\begin{array}{l}0.1209^{* * *} \\
(0.0448)\end{array}$ & $\begin{array}{l}0.1585^{\star * *} \\
(0.0332)\end{array}$ & $\begin{array}{l}0.2390^{* * *} \\
(0.0358)\end{array}$ & $\begin{array}{l}0.0811^{* * *} \\
(0.0298)\end{array}$ & $\begin{array}{c}0.0605 \\
(0.1992)\end{array}$ \\
\hline Proportion of children between $0-14$ & $\begin{array}{l}-0.0631 \\
(0.0667)\end{array}$ & $\begin{array}{l}-0.0323 \\
(0.0415)\end{array}$ & $\begin{array}{c}0.0471 \\
(0.0472)\end{array}$ & $\begin{array}{c}0.0001 \\
(0.0381)\end{array}$ & $\begin{array}{l}-0.1067 \\
(0.2745)\end{array}$ \\
\hline Age & $\begin{array}{l}0.0252^{* * *} \\
(0.0059)\end{array}$ & $\begin{array}{l}0.0171^{* * *} \\
(0.0039)\end{array}$ & $\begin{array}{l}0.0162^{* * *} \\
(0.0042)\end{array}$ & $\begin{array}{l}0.0097^{* * *} \\
(0.0035)\end{array}$ & $\begin{array}{l}-0.0466^{*} \\
(0.0255)\end{array}$ \\
\hline Age square & $\begin{array}{l}-0.0003^{* * *} \\
(0.0001)\end{array}$ & $\begin{array}{l}-0.0002^{* * *} \\
(0.0000)\end{array}$ & $\begin{array}{l}-0.0002^{* * *} \\
(0.0000)\end{array}$ & $\begin{array}{l}-0.0001^{* * *} \\
(0.0000)\end{array}$ & $\begin{array}{c}0.0005^{*} \\
(0.0003)\end{array}$ \\
\hline Schooling & $\begin{array}{l}0.0613^{\star * *} \\
(0.0133)\end{array}$ & $\begin{array}{l}0.0337^{\star * *} \\
(0.0091)\end{array}$ & $\begin{array}{c}0.0133 \\
(0.0115)\end{array}$ & $\begin{array}{l}-0.0302^{*} \\
(0.0175)\end{array}$ & $\begin{array}{l}-0.0484 \\
(0.0407)\end{array}$ \\
\hline Schooling square & $\begin{array}{l}-0.0041^{* * *} \\
(0.0011)\end{array}$ & $\begin{array}{l}-0.0024^{* * *} \\
(0.0007)\end{array}$ & $\begin{array}{l}-0.0005 \\
(0.0009)\end{array}$ & $\begin{array}{c}0.0026^{*} \\
(0.0014)\end{array}$ & $\begin{array}{c}0.0044 \\
(0.0029)\end{array}$ \\
\hline Proportion married & $\begin{array}{l}-0.0581^{*} \\
(0.0307)\end{array}$ & $\begin{array}{l}-0.0624^{* * *} \\
(0.0232)\end{array}$ & $\begin{array}{l}-0.0743^{\star * *} \\
(0.0277)\end{array}$ & $\begin{array}{l}-0.0077 \\
(0.0226)\end{array}$ & $\begin{array}{l}-0.0460 \\
(0.1606)\end{array}$ \\
\hline Proportion of whites & $\begin{array}{l}-0.1094^{\star * *} \\
(0.0197)\end{array}$ & $\begin{array}{l}-0.0730^{* * *} \\
(0.0139)\end{array}$ & $\begin{array}{l}-0.0692^{* * *} \\
(0.0184)\end{array}$ & $\begin{array}{l}-0.0303^{*} \\
(0.0163)\end{array}$ & $\begin{array}{c}0.0069 \\
(0.1011)\end{array}$ \\
\hline Proportion of urban population & $\begin{array}{l}-0.0478^{\star *} \\
(0.0227)\end{array}$ & $\begin{array}{l}-0.1223^{\star * *} \\
(0.0201)\end{array}$ & $\begin{array}{l}-0.1447^{\star * *} \\
(0.0463)\end{array}$ & $\begin{array}{c}0.0233 \\
(0.0376)\end{array}$ & $\begin{array}{l}-0.0582 \\
(0.2466)\end{array}$ \\
\hline Proportion in administrative occupations & $\begin{array}{l}-0.3698^{\star \star *} \\
(0.0357)\end{array}$ & $\begin{array}{l}-0.2363^{\star \star *} \\
(0.0263)\end{array}$ & $\begin{array}{l}-0.1455^{\star * *} \\
(0.0266)\end{array}$ & $\begin{array}{l}-0.0464^{*} \\
(0.0243)\end{array}$ & $\begin{array}{l}-0.0926 \\
(0.2081)\end{array}$ \\
\hline Proportion in service occupations & $(0.0255)$ & $\begin{array}{l}-0.1895^{* * *} \\
\text { Random } \\
(0.0188)\end{array}$ & $\begin{array}{c}-0.0749^{* * *} \\
\text { Fixed } \\
(0.0222)\end{array}$ & $\begin{array}{c}-0.0470^{* * *} \\
\text { First } \\
(0.0164)\end{array}$ & (0.1289) \\
\hline Proportion in commercial occupations & $\begin{array}{l}-0.2698^{\star * *} \\
(0.0341)\end{array}$ & $\begin{array}{l}-0.1463^{\star \star \star} \\
(0.0238)\end{array}$ & $\begin{array}{l}-0.0425^{*} \\
(0.0258)\end{array}$ & $\begin{array}{c}0.0023 \\
(0.0206)\end{array}$ & $\begin{array}{l}-0.0136 \\
(0.1799)\end{array}$ \\
\hline F-test: & 47.71 & 90378.07 & 35.84 & 1445.40 & 1.46 \\
\hline P-value & 0.0000 & 0.0000 & 0.0000 & 0.0000 & 0.1030 \\
\hline $\begin{array}{l}\text { Hausman test: } \chi^{2} \\
\text { P-value }\end{array}$ & & & $\begin{array}{l}184.25 \\
0.0000\end{array}$ & & \\
\hline $\begin{array}{l}\text { Hansen test: } \chi^{2} \\
\text { P-value }\end{array}$ & & & & & $\begin{array}{r}79.43 \\
0.3414\end{array}$ \\
\hline Number of observations & 4030 & 4030 & 4030 & 3224 & 2418 \\
\hline
\end{tabular}

Notes: All variables are mean sample values computed from microdata from PNAD across the years 2001-2005. The dependent variable is the proportion of individuals in the labour force at the municipality level. Robust standard errors are in parentheses. Significance levels: ${ }^{* * *}=1 \%,{ }^{* *}=5 \%,{ }^{*}=10 \%$. The models in columns (2) and (3) contain an intercept and dummies for geographical regions and metropolitan areas. The GMM model is estimated in first-differences and uses as instruments the levels of covariates lagged twice and earlier. All models contain year dummies. The municipal population summed over the years that are used in the regressions weights regressions. 
To assess the magnitude of the effect of interest we can calculate its elasticity at the mean values of $(y, p)=(0.558,0.136)$. Taking the point estimates at face value, their average equals approximately 0.04 , which gives an elasticity of around 0.01 . This implies that a $10 \%$ increase in the proportion of CCT beneficiaries would raise the female participation rate in $0.1 \%$, which is a very small impact. Hence, we may conclude that the effect of the Brazilian CCT programmes on the female participation rate does not seem to be significant either in magnitude or on statistical grounds.

The effects of labour and non-labour income are respectively positive and negative, and statistically significant across almost all models (the exception is the GMM estimate ${ }^{22}$ ). These are the expected signs. Indeed, there is abundant empirical evidence that shows that higher labour earnings affect positively the supply of labour (see e.g. BLUNDELL; MACURDY, 1999). Also, higher non-labour earnings can be seen as a pure income effect, so we would expect a negative impact of this variable on labour supply. ${ }^{23}$ Interestingly, higher unemployment rates seem to increase the participation rate of women. This may be due to women's decision to enter the labour force when their husbands become unemployed. Though not statistically significant, most estimates of the coefficient associated with the proportions of children in the municipality are negative. Hence, if anything, this may be indicating that children care activities inhibit women from participating in the labour market. Except for the GMM results, age seems to increase participation of women but at a decreasing rate. Similar results are observed for the schooling effect. Being married impacts negatively the labour force participation of females, a result that might be due to a lower necessity to work for married women.

A higher proportion of white females appears to be associated with lower participation rates. To the extent that labour supply decisions of black women may be affected by expectations of racial discrimination in the labour market, this result is unexpected. Some estimates of the effect of the proportion of females that live in urban areas are negative, whereas others are positive or statistically nil. In principle, the sign of this effect is ambiguous: on the one hand, urban areas tend to have more diversity in employment opportunities, which should lead to higher levels of labour force participation; on the other hand, rural individuals tend to help out in farm chores, a fact that should lead to lower participation levels in

22 Since instrumental variable estimation typically involves some loss of efficiency, it is not uncommon to lose statistical significance in this type of estimation.

23 A recent study for Brazil (REIS; CAMARGO, 2007) shows that non-labour earnings from pensions impact negatively the participation rate of men and women. 
rural areas. As for the occupational composition, most estimates indicate that higher shares of women in administrative, service, or commercial occupations tend to decrease female labour market participation (as compared to the excluded miscellaneous occupational category).

Table 6 reports the results for the participation rate of the below-median sample of females. Overall, the estimates of the effect of interest are quite similar to those obtained for the sample of all females. This is observed both in terms of the magnitude of the point estimates and in terms of statistical significance. Using the average of the point estimates (approximately 0.04), the elasticity of the effect of interest [calculated at the mean values of $(y, p)=(0.526,0.194)$ ] is around 0.01 , implying that a $10 \%$ increase in the proportion of CCT beneficiaries in Brazil would rise by $0.1 \%$ the participation rate of females whose per capita income is below the median per capita family income of the municipalities they live in. As in the case of all females, we may conclude that CCT programmes do not seem to significantly increase the participation rate of poorer females.The results for the rest of the covariates are also similar to those of the overall sample of females. What seems somewhat different is the higher magnitude of the impact of labour and non-labour income, and the unemployment rate. 
Table 6 - Effect of CCT Programmes on the Participation Rate of Females: BelowMedian Sample

\begin{tabular}{|c|c|c|c|c|c|}
\hline Covariates & $\begin{array}{l}\text { OLS } \\
(2) \\
\end{array}$ & $\begin{array}{l}\text { Random } \\
\text { Effects } \\
(3)\end{array}$ & $\begin{array}{c}\text { Fixed } \\
\text { Effects } \\
(4) \\
\end{array}$ & $\begin{array}{c}\text { First } \\
\text { Difference } \\
(5) \\
\end{array}$ & $\begin{array}{c}\text { GMM } \\
(6)\end{array}$ \\
\hline Proportion of beneficiaries & $\begin{array}{l}0.0765^{\star \star \star} \\
(0.0186)\end{array}$ & $\begin{array}{l}0.0603^{\star \star \star} \\
(0.0124)\end{array}$ & $\begin{array}{c}0.0160 \\
(0.0134)\end{array}$ & $\begin{array}{c}0.0146 \\
(0.0123)\end{array}$ & $\begin{array}{c}0.0120 \\
(0.0654)\end{array}$ \\
\hline Labour income (1/10) & $\begin{array}{l}0.0370^{\star \star \star} \\
(0.0023)\end{array}$ & $\begin{array}{l}0.0450^{\star \star \star} \\
(0.0023)\end{array}$ & $\begin{array}{l}0.0490^{\star \star \star} \\
(0.0024)\end{array}$ & $\begin{array}{l}0.0270^{\star * \star} \\
(0.0020)\end{array}$ & $\begin{array}{r}0.0279^{*} \\
(0.0152)\end{array}$ \\
\hline Non-labour income $(1 / 10)$ & $\begin{array}{l}-0.0104^{\star \star \star} \\
(0.0038)\end{array}$ & $\begin{array}{l}-0.0088^{\star \star \star} \\
(0.0031)\end{array}$ & $\begin{array}{l}-0.0081^{\star \star \star} \\
(0.0031)\end{array}$ & $\begin{array}{l}-0.0022 \\
(0.0024)\end{array}$ & $\begin{array}{l}0.0015 \\
(0.0249)\end{array}$ \\
\hline Unemployment rate & $\begin{array}{l}0.1891^{\star \star \star} \\
(0.0377)\end{array}$ & $\begin{array}{l}0.2524^{\star \star \star} \\
(0.0267)\end{array}$ & $\begin{array}{l}0.3513^{\star \star \star} \\
(0.0290)\end{array}$ & $\begin{array}{l}0.1524^{\star * \star} \\
(0.0243)\end{array}$ & $\begin{array}{r}0.3810^{*} \\
(0.2274)\end{array}$ \\
\hline Proportion of children between $0-14$ & $\begin{array}{l}-0.0415 \\
(0.0611)\end{array}$ & $\begin{array}{c}0.0249 \\
(0.0426)\end{array}$ & $\begin{array}{l}0.1098^{\star \star} \\
(0.0452)\end{array}$ & $\begin{array}{c}0.0132 \\
(0.0367)\end{array}$ & $\begin{array}{l}-0.2617 \\
(0.2957)\end{array}$ \\
\hline Age & $\begin{array}{l}0.0301^{* * \star} \\
(0.0051)\end{array}$ & $\begin{array}{l}0.0192^{\star * *} \\
(0.0036)\end{array}$ & $\begin{array}{l}0.0135^{\star \star *} \\
(0.0035)\end{array}$ & $\begin{array}{l}0.0092^{\star \star *} \\
(0.0033)\end{array}$ & $\begin{array}{l}-0.0358 \\
(0.0284)\end{array}$ \\
\hline Age square & $\begin{array}{l}-0.0004^{\star * *} \\
(0.0001)\end{array}$ & $\begin{array}{l}-0.0003^{\star * *} \\
(0.0000)\end{array}$ & $\begin{array}{l}-0.0002^{* * *} \\
(0.0000)\end{array}$ & $\begin{array}{l}-0.0001^{* * *} \\
(0.0000)\end{array}$ & $\begin{array}{r}0.0003 \\
(0.0003)\end{array}$ \\
\hline Schooling & $\begin{array}{c}0.0279 \\
(0.0172)\end{array}$ & $\begin{array}{c}0.0069 \\
(0.0115)\end{array}$ & $\begin{array}{l}-0.0134 \\
(0.0133)\end{array}$ & $\begin{array}{l}-0.0006 \\
(0.0179)\end{array}$ & $\begin{array}{l}-0.0517 \\
(0.0464)\end{array}$ \\
\hline Schooling square & $\begin{array}{l}-0.0020 \\
(0.0016)\end{array}$ & $\begin{array}{l}-0.0010 \\
(0.0011)\end{array}$ & $\begin{array}{c}0.0007 \\
(0.0013)\end{array}$ & $\begin{array}{l}-0.0004 \\
(0.0017)\end{array}$ & $\begin{array}{r}0.0048 \\
(0.0048)\end{array}$ \\
\hline Proportion married & $\begin{array}{l}-0.1180^{* * *} \\
(0.0302)\end{array}$ & $\begin{array}{l}-0.0607^{\star * *} \\
(0.0235)\end{array}$ & $\begin{array}{l}-0.0261 \\
(0.0252)\end{array}$ & $\begin{array}{c}0.0190 \\
(0.0213)\end{array}$ & $\begin{array}{l}-0.1301 \\
(0.2014)\end{array}$ \\
\hline Proportion of whites & $\begin{array}{l}-0.1243^{* * *} \\
(0.0197)\end{array}$ & $\begin{array}{l}-0.0620^{* * *} \\
(0.0148)\end{array}$ & $\begin{array}{l}-0.0315^{\star} \\
(0.0168)\end{array}$ & $\begin{array}{l}-0.0109 \\
(0.0148)\end{array}$ & $\begin{array}{c}0.1162 \\
(0.1205)\end{array}$ \\
\hline Proportion of urban population & $\begin{array}{l}-0.1131^{* * *} \\
(0.0234)\end{array}$ & $\begin{array}{l}-0.1684^{\star * *} \\
(0.0198)\end{array}$ & $\begin{array}{l}-0.1090^{\star \star *} \\
(0.0295)\end{array}$ & $\begin{array}{l}-0.0077 \\
(0.0254)\end{array}$ & $\begin{array}{l}-0.3002^{*} \\
(0.1706)\end{array}$ \\
\hline Proportion in administrative occupations & $\begin{array}{l}-0.3820^{* \star *} \\
(0.0401)\end{array}$ & $\begin{array}{l}-0.2567^{* \star *} \\
(0.0314)\end{array}$ & $\begin{array}{l}-0.2126^{* * *} \\
(0.0300)\end{array}$ & $\begin{array}{l}-0.0659^{* *} \\
(0.0261)\end{array}$ & $\begin{array}{c}0.0287 \\
(0.2953)\end{array}$ \\
\hline Proportion in service occupations & $\begin{array}{l}-0.2414^{* \star \star} \\
(0.0194)\end{array}$ & $\begin{array}{l}-0.1721^{\star \star *} \\
(0.0142)\end{array}$ & $\begin{array}{l}-0.0991^{\star \star *} \\
(0.0159)\end{array}$ & $\begin{array}{l}-0.0532^{\star \star \star} \\
(0.0120)\end{array}$ & $\begin{array}{l}-0.0450 \\
(0.1154)\end{array}$ \\
\hline Proportion in commercial occupations & $\begin{array}{l}-0.2147^{\star \star \star} \\
(0.0274) \\
\end{array}$ & $\begin{array}{l}-0.1214^{\star * \star} \\
(0.0226)\end{array}$ & $\begin{array}{l}-0.0526^{* *} \\
(0.0232)\end{array}$ & $\begin{array}{l}-0.0109 \\
(0.0181) \\
\end{array}$ & $\begin{array}{l}-0.1398 \\
(0.1569) \\
\end{array}$ \\
\hline F-test: & 49.07 & 48281.49 & 43.30 & 897.82 & 1.57 \\
\hline P-value & 0.0000 & 0.0000 & 0.0000 & 0.0000 & 0.0647 \\
\hline Hausman test: $\chi^{2}$ & & & 224.05 & & \\
\hline $\begin{array}{l}\text { Hansen test: } \chi^{2} \\
\text { P-value }\end{array}$ & & & & & $\begin{array}{r}90.85 \\
0.1027\end{array}$ \\
\hline Number of observations & 4030 & 4030 & 4030 & 3224 & 2418 \\
\hline
\end{tabular}

Notes: See Table 5. The below-median sample refers to females who are below the median per capita family income of the municipalities they live in. 


\subsubsection{Males}

Table 7 presents the results for the participation rate for the overall sample of males. All point estimates of the effect of interest are positive and, except for the GMM case, also statistically different from zero at conventional levels. Calculated for the average of the point estimates (approximately 0.03) and at the mean values of $(y, p)=(0.810,0.136)$, the implied elasticity here is around 0.005 . This implies that a $10 \%$ increase in the proportion of CCT beneficiaries would raise the male participation rate by $0.05 \%$. Though very small in magnitude, here we may conclude that the impact seems positive and statistically significant.

The effects of labour and non-labour income are respectively positive and negative, though they seem to be smaller in absolute value than those obtained for all females. The unemployment rate seems to increase the participation rate of males, a result that has also been observed for women. In fact, the effects of the other covariates tend to be similar to what has been observed for the other gender group. The main exception is the variable proportion married, whose effect seems to be positive in the case of males. This may be due to the fact that males feel more compelled to be in the labour force when they are married.

Table 8 displays the results for the participation rate of the below-median sample of males. Estimates of the effect of interest are similar to those of the overall sample of males: all point estimates are positive and, except for the GMM, also statistically significant. Using again the average of the all point estimates (approximately 0.04) and the mean values of $(y, p)=(0.807,0.194)$, the elasticity is around 0.01 , implying that a $10 \%$ increase in the proportion of CCT beneficiaries would lead to a $0.1 \%$ in the participation rate of poorer males. Though this impact is somewhat higher than that obtained for all males, it is still quite small. 
Table 7 - Effect of CCT Programmes on the Participation Rate of Males: Overall Sample

\begin{tabular}{|c|c|c|c|c|c|}
\hline Covariates & $\begin{array}{l}\text { OLS } \\
(2)\end{array}$ & $\begin{array}{c}\text { Random } \\
\text { Effects } \\
\text { (3) }\end{array}$ & $\begin{array}{c}\text { Fixed } \\
\text { Effects } \\
(4)\end{array}$ & $\begin{array}{c}\text { First } \\
\text { Difference } \\
\text { (5) }\end{array}$ & $\begin{array}{l}\text { GMM } \\
(6)\end{array}$ \\
\hline Proportion of beneficiaries & $\begin{array}{l}0.0390^{\star * \star} \\
(0.0104)\end{array}$ & $\begin{array}{l}0.0391^{\star * \star} \\
(0.0076)\end{array}$ & $\begin{array}{l}0.0193^{\star *} \\
(0.0090)\end{array}$ & $\begin{array}{l}0.0274^{* \star \star} \\
(0.0102)\end{array}$ & $\begin{array}{c}0.0146 \\
(0.0515)\end{array}$ \\
\hline Labour income (1/10) & $\begin{array}{l}0.0010^{\star * *} \\
(0.0001)\end{array}$ & $\begin{array}{l}0.0008^{\star * *} \\
(0.0001)\end{array}$ & $\begin{array}{l}0.0008^{\star \star *} \\
(0.0001)\end{array}$ & $\begin{array}{l}0.0006^{* * *} \\
(0.0001)\end{array}$ & $\begin{array}{l}0.0001 \\
(0.0005)\end{array}$ \\
\hline Non-labour income $(1 / 10)$ & $\begin{array}{l}-0.0022^{* * *} \\
(0.0002)\end{array}$ & $\begin{array}{l}-0.0020^{\star * *} \\
(0.0002)\end{array}$ & $\begin{array}{l}-0.0012^{* \star *} \\
(0.0003)\end{array}$ & $\begin{array}{l}-0.0005^{* *} \\
(0.0002)\end{array}$ & $\begin{array}{l}-0.0006 \\
(0.0014)\end{array}$ \\
\hline Unemployment rate & $\begin{array}{l}-0.0398 \\
(0.0264)\end{array}$ & $\begin{array}{c}0.0174 \\
(0.0212)\end{array}$ & $\begin{array}{l}0.1368^{\star \star *} \\
(0.0232)\end{array}$ & $\begin{array}{l}0.0795^{\star * *} \\
(0.0213)\end{array}$ & $\begin{array}{c}0.0451 \\
(0.1457)\end{array}$ \\
\hline Proportion of children between $0-14$ & $\begin{array}{l}-0.0312 \\
(0.0376)\end{array}$ & $\begin{array}{c}0.0107 \\
(0.0280)\end{array}$ & $\begin{array}{l}0.0952^{* \star *} \\
(0.0352)\end{array}$ & $\begin{array}{c}0.0026 \\
(0.0265)\end{array}$ & $\begin{array}{l}-0.2121 \\
(0.1977)\end{array}$ \\
\hline Age & $\begin{array}{l}0.0249^{\star \star \star} \\
(0.0031)\end{array}$ & $\begin{array}{l}0.0253^{\star \star *} \\
(0.0024)\end{array}$ & $\begin{array}{l}0.0271^{\star \star \star} \\
(0.0028)\end{array}$ & $\begin{array}{l}0.0143^{\star * *} \\
(0.0021)\end{array}$ & $\begin{array}{l}0.0377^{\star \star} \\
(0.0152)\end{array}$ \\
\hline Age square & $\begin{array}{l}-0.0003^{* * *} \\
(0.0000)\end{array}$ & $\begin{array}{l}-0.0003^{* * *} \\
(0.0000)\end{array}$ & $\begin{array}{l}-0.0003^{* \star *} \\
(0.0000)\end{array}$ & $\begin{array}{l}-0.0002^{* * *} \\
(0.0000)\end{array}$ & $\begin{array}{l}-0.0005^{* * *} \\
(0.0002)\end{array}$ \\
\hline Schooling & $\begin{array}{l}-0.0037 \\
(0.0044)\end{array}$ & $\begin{array}{l}-0.0027 \\
(0.0041)\end{array}$ & $\begin{array}{l}-0.0012 \\
(0.0062)\end{array}$ & $\begin{array}{l}0.0450^{* * *} \\
(0.0101)\end{array}$ & $\begin{array}{l}-0.0324 \\
(0.0234)\end{array}$ \\
\hline Schooling square & $\begin{array}{l}-0.0004 \\
(0.0003)\end{array}$ & $\begin{array}{l}-0.0001 \\
(0.0003)\end{array}$ & $\begin{array}{l}0.0006 \\
(0.0005)\end{array}$ & $\begin{array}{l}-0.0035^{* \star *} \\
(0.0008)\end{array}$ & $\begin{array}{c}0.0021 \\
(0.0016)\end{array}$ \\
\hline Proportion married & $\begin{array}{l}0.1404^{\star \star *} \\
(0.0213)\end{array}$ & $\begin{array}{l}0.0979^{\star \star \star} \\
(0.0172)\end{array}$ & $\begin{array}{r}0.0381^{*} \\
(0.0196)\end{array}$ & $\begin{array}{l}0.0373^{* *} \\
(0.0174)\end{array}$ & $\begin{array}{l}0.0591 \\
(0.1351)\end{array}$ \\
\hline Proportion of whites & $\begin{array}{l}-0.0387^{\star * *} \\
(0.0099)\end{array}$ & $\begin{array}{l}-0.0158^{*} \\
(0.0083)\end{array}$ & $\begin{array}{l}-0.0360^{\star * *} \\
(0.0117)\end{array}$ & $\begin{array}{l}-0.0058 \\
(0.0121)\end{array}$ & $\begin{array}{l}-0.0185 \\
(0.0723)\end{array}$ \\
\hline Proportion of urban population & $\begin{array}{l}-0.0657^{\star * *} \\
(0.0097)\end{array}$ & $\begin{array}{l}-0.0945^{\star * *} \\
(0.0089) \\
\text { Random }\end{array}$ & $\begin{array}{c}-0.1326^{\star * *} \\
(0.0222) \\
\text { Fixed }\end{array}$ & $\begin{array}{c}-0.0242 \\
(0.0204) \\
\text { First }\end{array}$ & $\begin{array}{l}-0.0623 \\
(0.1672)\end{array}$ \\
\hline Proportion in administrative occupations & $\begin{array}{l}-0.0731^{* *} \\
(0.0361)\end{array}$ & $\begin{array}{l}-0.0462 \\
(0.0304)\end{array}$ & $\begin{array}{l}-0.0163 \\
(0.0314)\end{array}$ & $\begin{array}{c}0.0059 \\
(0.0285)\end{array}$ & $\begin{array}{l}-0.0977 \\
(0.1979)\end{array}$ \\
\hline Proportion in service occupations & $\begin{array}{l}-0.1128^{\star * *} \\
(0.0208)\end{array}$ & $\begin{array}{l}-0.0618^{\star \star *} \\
(0.0185)\end{array}$ & $\begin{array}{c}0.0155 \\
(0.0199)\end{array}$ & $\begin{array}{l}-0.0798^{\star * *} \\
(0.0213)\end{array}$ & $\begin{array}{r}0.3057^{\star} \\
(0.1622)\end{array}$ \\
\hline Proportion in commercial occupations & $\begin{array}{l}-0.1544^{\star * *} \\
(0.0284)\end{array}$ & $\begin{array}{l}-0.0987^{\star * *} \\
(0.0226)\end{array}$ & $\begin{array}{l}-0.0102 \\
(0.0237) \\
\end{array}$ & $\begin{array}{l}-0.0181 \\
(0.0206) \\
\end{array}$ & $\begin{array}{l}-0.2891^{*} \\
(0.1562)\end{array}$ \\
\hline F-test: & 114.15 & 569505.77 & 31.74 & 6905.91 & 1.85 \\
\hline P-value & 0.0000 & 0.0000 & 0.0000 & 0.0000 & 0.0195 \\
\hline $\begin{array}{l}\text { Hausman test: } \chi^{2} \\
\text { P-value }\end{array}$ & & & $\begin{array}{l}208.10 \\
0.0000\end{array}$ & & \\
\hline $\begin{array}{l}\text { Hansen test: } \chi^{2} \\
\text { P-value }\end{array}$ & & & & & $\begin{array}{r}52.77 \\
0.9760\end{array}$ \\
\hline Number of observations & 4030 & 4030 & 4030 & 3224 & 2418 \\
\hline
\end{tabular}

Notes: See Table 5. 
Table 8 - Effect of CCT Programmes on the Participation Rate of Males: BelowMedian Sample

\begin{tabular}{|c|c|c|c|c|c|}
\hline Covariates & $\begin{array}{l}\text { OLS } \\
(2)\end{array}$ & $\begin{array}{l}\text { Random } \\
\text { Effects } \\
\text { (3) }\end{array}$ & $\begin{array}{c}\text { Fixed } \\
\text { Effects } \\
(4)\end{array}$ & $\begin{array}{c}\text { First } \\
\text { Difference } \\
(5)\end{array}$ & $\begin{array}{l}\text { GMM } \\
(6)\end{array}$ \\
\hline Proportion of beneficiaries & $\begin{array}{l}0.0566^{\star \star \star} \\
(0.0082)\end{array}$ & $\begin{array}{l}0.0503^{\star \star \star} \\
(0.0067)\end{array}$ & $\begin{array}{l}0.0193^{* \star} \\
(0.0081)\end{array}$ & $\begin{array}{l}0.0372^{\star \star *} \\
(0.0092)\end{array}$ & $\begin{array}{c}0.0280 \\
(0.0491)\end{array}$ \\
\hline Labour income (1/10) & $\begin{array}{l}0.0100^{* * *} \\
(0.0007)\end{array}$ & $\begin{array}{l}0.0108^{* * *} \\
(0.0006)\end{array}$ & $\begin{array}{l}0.0131^{\star \star *} \\
(0.0008)\end{array}$ & $\begin{array}{l}0.0079^{* * *} \\
(0.0008)\end{array}$ & $\begin{array}{c}0.0033 \\
(0.0046)\end{array}$ \\
\hline Non-labour income $(1 / 10)$ & $\begin{array}{l}-0.0265^{\star \star \star} \\
(0.0022)\end{array}$ & $\begin{array}{l}-0.0279^{\star * \star} \\
(0.0023)\end{array}$ & $\begin{array}{l}-0.0236^{\star * \star} \\
(0.0023)\end{array}$ & $\begin{array}{l}-0.0122^{\star \star \star} \\
(0.0018)\end{array}$ & $\begin{array}{l}-0.0134 \\
(0.0101)\end{array}$ \\
\hline Unemployment rate & $\begin{array}{c}0.0396^{*} \\
(0.0205)\end{array}$ & $\begin{array}{l}0.0784^{\star \star \star} \\
(0.0179)\end{array}$ & $\begin{array}{l}0.1990^{* * *} \\
(0.0216)\end{array}$ & $\begin{array}{l}0.1051^{\star * *} \\
(0.0175)\end{array}$ & $\begin{array}{c}0.0726 \\
(0.1174)\end{array}$ \\
\hline Proportion of children between $0-14$ & $\begin{array}{c}0.0084 \\
(0.0313)\end{array}$ & $\begin{array}{l}0.0824^{\star * *} \\
(0.0279)\end{array}$ & $\begin{array}{l}0.1780^{\star \star \star} \\
(0.0330)\end{array}$ & $\begin{array}{c}0.0572^{\star *} \\
(0.0275)\end{array}$ & $\begin{array}{c}0.1658 \\
(0.1878)\end{array}$ \\
\hline Age & $\begin{array}{l}0.0180^{\star * *} \\
(0.0026)\end{array}$ & $\begin{array}{l}0.0181^{\star * *} \\
(0.0024)\end{array}$ & $\begin{array}{l}0.0155^{\star \star \star} \\
(0.0026)\end{array}$ & $\begin{array}{l}0.0129^{\star \star *} \\
(0.0023)\end{array}$ & $\begin{array}{l}0.0430^{* * *} \\
(0.0153)\end{array}$ \\
\hline Age square & $\begin{array}{l}-0.0002^{\star * *} \\
(0.0000)\end{array}$ & $\begin{array}{l}-0.0002^{\star * *} \\
(0.0000)\end{array}$ & $\begin{array}{l}-0.0002^{* * \star} \\
(0.0000)\end{array}$ & $\begin{array}{l}-0.0002^{\star * \star} \\
(0.0000)\end{array}$ & $\begin{array}{l}-0.0005^{\star \star \star} \\
(0.0002)\end{array}$ \\
\hline Schooling & $\begin{array}{l}-0.0194^{\star * *} \\
(0.0052)\end{array}$ & $\begin{array}{l}-0.0111^{\star *} \\
(0.0047)\end{array}$ & $\begin{array}{l}-0.0055 \\
(0.0064)\end{array}$ & $\begin{array}{l}0.0486^{\star * *} \\
(0.0077)\end{array}$ & $\begin{array}{l}-0.0086 \\
(0.0255)\end{array}$ \\
\hline Schooling square & $\begin{array}{l}0.0015^{\star * *} \\
(0.0005)\end{array}$ & $\begin{array}{l}0.0010^{* *} \\
(0.0005)\end{array}$ & $\begin{array}{c}0.0009 \\
(0.0006)\end{array}$ & $\begin{array}{l}-0.0049^{* * *} \\
(0.0008)\end{array}$ & $\begin{array}{l}0.0015 \\
(0.0024)\end{array}$ \\
\hline Proportion married & $\begin{array}{l}0.1327^{\star * *} \\
(0.0178)\end{array}$ & $\begin{array}{l}0.1044^{\star * *} \\
(0.0159)\end{array}$ & $\begin{array}{l}0.0831^{* * *} \\
(0.0185)\end{array}$ & $\begin{array}{r}0.0272^{*} \\
(0.0163)\end{array}$ & $\begin{array}{l}-0.0729 \\
(0.1118)\end{array}$ \\
\hline Proportion of whites & $\begin{array}{l}-0.0500^{\star * *} \\
(0.0100)\end{array}$ & $\begin{array}{l}-0.0297^{\star * *} \\
(0.0087)\end{array}$ & $\begin{array}{l}-0.0379^{* \star *} \\
(0.0119)\end{array}$ & $\begin{array}{l}-0.0204^{\star *} \\
(0.0103)\end{array}$ & $\begin{array}{c}0.0168 \\
(0.0748)\end{array}$ \\
\hline Proportion of urban population & $\begin{array}{l}-0.0894^{\star \star \star} \\
(0.0089)\end{array}$ & $\begin{array}{l}-0.1099^{\star \star \star} \\
(0.0081)\end{array}$ & $\begin{array}{l}-0.1194^{\star \star \star} \\
(0.0161)\end{array}$ & $\begin{array}{l}-0.0386^{\star \star \star} \\
(0.0134)\end{array}$ & $\begin{array}{l}-0.1153 \\
(0.1154)\end{array}$ \\
\hline Proportion in administrative occupations & $\begin{array}{l}-0.0668^{*} \\
(0.0365)\end{array}$ & $\begin{array}{l}-0.0672^{\star *} \\
(0.0336)\end{array}$ & $\begin{array}{l}-0.0163 \\
(0.0350)\end{array}$ & $\begin{array}{l}-0.0412 \\
(0.0313)\end{array}$ & $\begin{array}{l}-0.0054 \\
(0.2100)\end{array}$ \\
\hline Proportion in service occupations & $\begin{array}{l}-0.0534^{\star \star \star} \\
(0.0146)\end{array}$ & $\begin{array}{l}-0.0359^{\star \star} \\
(0.0146)\end{array}$ & $\begin{array}{c}0.0119 \\
(0.0168)\end{array}$ & $\begin{array}{l}-0.0586^{\star \star \star} \\
(0.0167)\end{array}$ & $\begin{array}{c}0.1881 \\
(0.1268)\end{array}$ \\
\hline Proportion in commercial occupations & $\begin{array}{l}-0.1326^{* \star *} \\
(0.0226)\end{array}$ & $\begin{array}{l}-0.1128^{* \star *} \\
(0.0219)\end{array}$ & $\begin{array}{l}-0.0333 \\
(0.0237)\end{array}$ & $\begin{array}{l}-0.0265 \\
(0.0186)\end{array}$ & $\begin{array}{l}-0.2972^{\star *} \\
(0.1399)\end{array}$ \\
\hline F-test: & 96.02 & 424969.57 & 49.42 & 5397.55 & 2.31 \\
\hline P-value & 0.0000 & 0.0000 & 0.0000 & 0.0000 & 0.0020 \\
\hline $\begin{array}{l}\text { Hausman test: } \chi^{2} \\
\text { P-value }\end{array}$ & & & $\begin{array}{l}157.90 \\
0.0000\end{array}$ & & \\
\hline Hansen test: $\chi^{2}$ & & & & & 63.20 \\
\hline P-value & & & & & 0.8325 \\
\hline Number of observations & 4030 & 4030 & 4030 & 3224 & 2418 \\
\hline
\end{tabular}

Notes: See Table 5. The below-median sample refers to males who are below the median per capita family income of the municipalities they live in. 
Similar to the comparison between the two samples of females, here it is also noticeable that labour income, non-labour income, and the unemployment rate have higher impacts (in absolute value) than those observed for overall sample of males. The rest of the results are also similar between the two samples of males.

\subsection{Hours Worked}

We now discuss the regression results for the case in which the response variable is the mean number of hours worked at the municipal level. It is important to recall that this variable has been measured including those individuals that worked zero hours (i.e. the unemployed and those out of the labour force). This implies that shifts in our measure of the mean number of hours worked are driven either by changes in the proportion of individuals with zero hours or by changes in the mean of strictly positive hours of work.

More formally, let $h$ denote the individual labour supply of hours, $\pi$ the proportion of individuals with $h=0$, and $\mu^{*}=E[h \mid h>0]$ the mean of the distribution of strictly positive hours. Then, the mean number of hours worked can be written as: $\mu=E[h]=\pi \cdot E[h \mid h=0]+(1-\pi) \cdot E[h \mid h>0]=(1-\pi) \cdot \mu^{*}$. Thus, $\mu$ can be affected either by changes in $\pi$ or in $\mu^{*}$.

CCT programmes may directly affect both $\pi$ and $\mu^{*}{ }^{24}$ For example, $\pi$ can vary because these programmes may make some of those who are out of the labour force to find a job. Also, $\mu^{*}$ can change because these programmes may directly affect the supply decisions of hours of those already employed. Moreover, changes in $\pi$ can indirectly affect $\mu^{*}$. For instance, using the previous example, if the group of newly employed individuals (i.e. those who moved from out of the labour force) has average hours below (above) the initial $\mu^{*}$, then we should observe a decrease (increase) in $\mu^{*}$.

It is not straightforward to connect the effects of CCT programmes on the supply of hours and the participation rate. First, there is an intrinsic relationship between the proportion of individuals with zero hours of work and the participation rate. ${ }^{25}$ Since CCT programmes may trigger movements of individuals across the different labour market statuses (employment, unemployment, and inactivity), it is possible that: (1) the participation rate and proportion of zero-hours individuals change in

24 For simplicity we omit conditioning variables in the notation for $\pi$ and $\mu^{*}$. It should be understood, however, that $\pi=\operatorname{Pr}[h=0 \mid p, X]$ and $\mu^{*}=E[h \mid h>0, p, X]$, where $p$ denotes programme participation and $X$ represent a vector of control variables.

25 To see this, denote by $P$ the population over 15 years of age, and let it be partitioned into three groups: those who are employed (e), those who are unemployed $(u)$, and those who are out of the labour force $(f)$. Denoting the participation rate by $r$, we can thus write: $r=(e+u) / P$ and $\pi=$ $(u+f) / P$, which clearly shows that two variables are inter-related. 
different directions; (2) one of them does not change at all; (3) they both change in the same direction. ${ }^{26}$ Second, as discussed in the previous paragraph, the mean of strictly positive hours $\left(\mu^{*}\right)$ may be indirectly affected by changes in proportion of individuals with zero hours of work. In this sense, since the participation rate and the proportion of zero-hours individuals are intertwined, this channel also contributes to make the link between total labour supply of hours (i.e. $\mu$ ) and the participation rate less direct. In fact, in order to investigate empirically the connection between the effects of CCT programmes on these two variables, it seems necessary to develop a method that is capable of isolating the programmes' effects on the set of all relevant variables that affect the total labour supply of hours. This task is beyond the scope of this paper, though.

\subsubsection{Females}

Table 9 reports the results for the overall sample of females. As it can be seen from this Table, all point estimates of the effect of interest are negative, with three out of five being statistically significant. In terms of magnitude, if we take the average of all estimates (approximately -1.6), the elasticity [calculated at the mean values of $(y, p)=(17.7,0.136)]$ is around -0.01 . This implies that the impact of a $10 \%$ increase in the proportion of CCT beneficiaries would reduce in $0.1 \%$ the mean number of hours worked by females. Though negative, this appears to be a small impact.

It is interesting to note that the effects of the Brazilian CCT programmes on the mean number of hours worked and the participation rate of females seem to be different. Indeed, the evidence shows that the impact is approximately nil on the participation rate of women but negative on their supply of hours. As discussed before, since there are various different channels through which these two effects may be connected, it is difficult to offer an explanation for this result.

The signs of the effects of the other covariates are similar to those found for the participation rate. A noticeable exception is the unemployment rate, whose effect on hours is negative.

26 The previous example can provide a case in which these variables move in opposite directions. Indeed, using the notation of footnote 25 and assuming that $P$ is constant, a movement from part of $f$ into e decreases $\pi$ and increases $r$. Assuming again that $P$ is constant, an example in which only one of these variable does not change value (namely r) would occur if there is movement between $u$ and $e$ with $f$ fixed. Finally, if there is an expansion in $P$ that leads solely to an increase in $u$, we should observe both $\mathrm{r}$ and $\pi$ moving in the same direction (specifically they both increase). 
Table 9 - Effect of CCT Programmes on Hours Worked of Females: Overall Sample

\begin{tabular}{|c|c|c|c|c|c|}
\hline Covariates & $\begin{array}{c}\text { OLS } \\
(2)\end{array}$ & $\begin{array}{l}\text { Random } \\
\text { Effects } \\
(3) \\
\end{array}$ & $\begin{array}{c}\text { Fixed } \\
\text { Effects } \\
(4)\end{array}$ & $\begin{array}{c}\text { First } \\
\text { Difference } \\
(5) \\
\end{array}$ & $\begin{array}{c}\text { GMM } \\
(6)\end{array}$ \\
\hline Proportion of beneficiaries & $\begin{array}{l}-1.4585^{\star \star} \\
(0.6205)\end{array}$ & $\begin{array}{l}-1.0271^{\star \star \star} \\
(0.3617)\end{array}$ & $\begin{array}{l}-0.6524 \\
(0.5379)\end{array}$ & $\begin{array}{l}-2.6266^{* \star *} \\
(0.6191)\end{array}$ & $\begin{array}{l}-2.3830 \\
(2.0709)\end{array}$ \\
\hline Labour income (1/10) & $\begin{array}{l}0.1961^{\star \star \star} \\
(0.0210)\end{array}$ & $\begin{array}{l}0.2005^{\star \star \star} \\
(0.0088)\end{array}$ & $\begin{array}{l}0.2194^{\star \star \star} \\
(0.0170)\end{array}$ & $\begin{array}{l}0.1158^{\star * *} \\
(0.0136)\end{array}$ & $\begin{array}{c}0.1068 \\
(0.0793)\end{array}$ \\
\hline Non-labour income $(1 / 10)$ & $\begin{array}{l}-0.1307^{\star \star *} \\
(0.0202)\end{array}$ & $\begin{array}{l}-0.1075^{\star \star \star} \\
(0.0141)\end{array}$ & $\begin{array}{l}-0.0684^{* * *} \\
(0.0184)\end{array}$ & $\begin{array}{l}-0.0400^{\star \star} \\
(0.0166)\end{array}$ & $\begin{array}{l}-0.0207 \\
(0.1163)\end{array}$ \\
\hline Unemployment rate & $\begin{array}{c}-18.5929^{\star * *} \\
(1.5306)\end{array}$ & $\begin{array}{c}-16.7559^{\star * *} \\
(0.9785)\end{array}$ & $\begin{array}{c}-15.2628^{\star * *} \\
(1.0829)\end{array}$ & $\begin{array}{l}-8.7690^{* * *} \\
(1.1643)\end{array}$ & $\begin{array}{c}-16.2545^{* *} \\
(8.0390)\end{array}$ \\
\hline Proportion of children between $0-14$ & $\begin{array}{l}-2.8796 \\
(2.3694)\end{array}$ & $\begin{array}{c}0.9053 \\
(1.3244)\end{array}$ & $\begin{array}{c}2.1828 \\
(1.6180)\end{array}$ & $\begin{array}{c}3.3829^{*} \\
(1.7691)\end{array}$ & $\begin{array}{c}-3.8405 \\
(10.7241)\end{array}$ \\
\hline Age & $\begin{array}{l}1.0411^{\star \star \star} \\
(0.2005)\end{array}$ & $\begin{array}{l}0.8222^{\star \star \star} \\
(0.1229)\end{array}$ & $\begin{array}{l}0.7663^{\star \star \star} \\
(0.1464)\end{array}$ & $\begin{array}{l}0.4442^{\star \star *} \\
(0.1384)\end{array}$ & $\begin{array}{l}-1.3847 \\
(0.8700)\end{array}$ \\
\hline Age square & $\begin{array}{l}-0.0141^{* * *} \\
(0.0022)\end{array}$ & $\begin{array}{l}-0.0109^{\star * *} \\
(0.0013)\end{array}$ & $\begin{array}{l}-0.0099^{* * *} \\
(0.0016)\end{array}$ & $\begin{array}{l}-0.0054^{\star * *} \\
(0.0016)\end{array}$ & $\begin{array}{c}0.0151 \\
(0.0096)\end{array}$ \\
\hline Schooling & $\begin{array}{l}3.0372^{* * *} \\
(0.4223)\end{array}$ & $\begin{array}{l}1.2467^{\star * *} \\
(0.2603)\end{array}$ & $\begin{array}{c}0.1818 \\
(0.4361)\end{array}$ & $\begin{array}{l}-4.4180^{* * *} \\
(0.6282)\end{array}$ & $\begin{array}{l}-0.8848 \\
(1.2524)\end{array}$ \\
\hline Schooling square & $\begin{array}{l}-0.2314^{* * *} \\
(0.0350)\end{array}$ & $\begin{array}{l}-0.0860^{* * *} \\
(0.0206)\end{array}$ & $\begin{array}{c}0.0171 \\
(0.0339)\end{array}$ & $\begin{array}{l}0.3738^{\star * *} \\
(0.0496)\end{array}$ & $\begin{array}{c}0.0873 \\
(0.0905)\end{array}$ \\
\hline Proportion married & $\begin{array}{l}-5.0810^{\star \star \star} \\
(1.0301)\end{array}$ & $\begin{array}{l}-4.9810^{\star \star \star} \\
(0.7787)\end{array}$ & $\begin{array}{l}-5.6113^{\star \star \star} \\
(0.8706)\end{array}$ & $\begin{array}{l}-2.9856^{\star \star \star} \\
(0.9573)\end{array}$ & $\begin{array}{l}-4.9769 \\
(7.0995)\end{array}$ \\
\hline Proportion of whites & $\begin{array}{l}-0.6220 \\
(0.5693)\end{array}$ & $\begin{array}{l}-0.9371^{\star *} \\
(0.4101)\end{array}$ & $\begin{array}{l}-1.3794^{\star *} \\
(0.5537)\end{array}$ & $\begin{array}{l}-1.1175^{\star \star} \\
(0.5621)\end{array}$ & $\begin{array}{c}0.1409 \\
(3.9200)\end{array}$ \\
\hline Proportion of urban population & $\begin{array}{c}0.5451 \\
(0.8091)\end{array}$ & $\begin{array}{l}-1.7028^{\star * \star} \\
(0.5571)\end{array}$ & $\begin{array}{l}-3.6178^{\star *} \\
(1.4299)\end{array}$ & $\begin{array}{c}0.2405 \\
(1.4168)\end{array}$ & $\begin{array}{c}6.3285 \\
(9.3572)\end{array}$ \\
\hline Proportion in administrative occupations & $\begin{array}{l}-9.1480^{* * \star} \\
(1.2446)\end{array}$ & $\begin{array}{l}-3.8009^{\star \star \star} \\
(0.8515)\end{array}$ & $\begin{array}{l}-1.6881^{*} \\
(0.9729)\end{array}$ & $\begin{array}{l}-0.6317 \\
(0.9999)\end{array}$ & $\begin{array}{l}-2.0769 \\
(6.8999)\end{array}$ \\
\hline Proportion in service occupations & $\begin{array}{l}-5.8759^{* * *} \\
(0.8517)\end{array}$ & $\begin{array}{l}-0.0395 \\
(0.5300)\end{array}$ & $\begin{array}{l}2.6156^{\star * *} \\
(0.7103)\end{array}$ & $\begin{array}{l}1.2695^{\star} \\
(0.6481)\end{array}$ & $\begin{array}{c}6.8951 \\
(4.3442)\end{array}$ \\
\hline Proportion in commercial occupations & $\begin{array}{l}-3.8321^{\star \star \star} \\
(1.1287)\end{array}$ & $\begin{array}{c}0.7889 \\
(0.7430)\end{array}$ & $\begin{array}{l}2.4720^{\star \star \star} \\
(0.8385)\end{array}$ & $\begin{array}{r}1.5014^{*} \\
(0.8376)\end{array}$ & $\begin{array}{l}5.9166 \\
(6.2977)\end{array}$ \\
\hline F-test: & 64.35 & 2042.76 & 50.46 & 959.02 & 2.10 \\
\hline P-value & 0.0000 & 0.0000 & 0.0000 & 0.0000 & 0.0057 \\
\hline $\begin{array}{l}\text { Hausman test: } \chi^{2} \\
\text { P-value }\end{array}$ & & & $\begin{array}{l}214.60 \\
0.0000\end{array}$ & & \\
\hline $\begin{array}{l}\text { Hansen test: } \chi^{2} \\
\text { P-value }\end{array}$ & & & & & $\begin{array}{r}68.62 \\
0.6851\end{array}$ \\
\hline Number of observations & 4030 & 4030 & 4030 & 3224 & 2418 \\
\hline \multicolumn{6}{|c|}{$\begin{array}{l}\text { Notes: All variables are mean sample values computed from microdata from PNAD across the year } \\
\text { 2001-2005. The dependent variable is the mean number of hours worked at the municipalit } \\
\text { level. Robust standard errors are in parentheses. Significance levels: }{ }^{* * *}=1 \%,{ }^{* *}=5 \%,{ }^{*}= \\
10 \% \text {. The models in columns (2) and (3) contain an intercept and dummies for geographica } \\
\text { regions and metropolitan areas. The GMM model is estimated in first-differences and use } \\
\text { as instruments the levels of covariates lagged twice and earlier. All models contain yea } \\
\text { dummies. The municipal population summed over the years that are used in the regression } \\
\text { weights regressions. }\end{array}$} \\
\hline
\end{tabular}


Table 10 contains the results for the below-median sample of females. All point estimates of the effect of interest display a negative sign, but only one of them is statistically significant at the $10 \%$ level. ${ }^{27}$ From the average of the point estimates (approximately -0.47), the elasticity [calculated at the mean values of $(y, p)=(14.5,0.194)]$ is close to -0.01 , implying that a rise in $10 \%$ in the proportion of CCT beneficiaries would lead to a reduction in $-0.1 \%$ in the mean number of hours worked by females below the their respective municipalities' median per capita income. Once again, the impact is quite small. In contrast to the case of all females, here the effect of interest does not seem to be statistically different from zero. Hence, for this sample, the effects on both the participation rate and the supply of hours are not significant either statistically or in magnitude.

In terms of sign, the effects of the other covariates are in line with those obtained for the overall sample of females. The magnitude of the effects associated with labour and non-labour income is higher (in absolute terms) for the below-median sample of females. The opposite applies for the unemployment rate.

27 Here, the validity of the orthogonality conditions of the GMM model is not rejected only at the $5 \%$ level by the Hansen test of overidentifying restrictions. 
Table 10 - Effect of CCT Programmes on Hours Worked of Females: Below-Median Sample

\begin{tabular}{|c|c|c|c|c|c|}
\hline Covariates & $\begin{array}{l}\text { OLS } \\
(2)\end{array}$ & $\begin{array}{c}\text { Effects } \\
(3)\end{array}$ & $\begin{array}{c}\text { Effects } \\
(4)\end{array}$ & $\begin{array}{c}\text { Difference } \\
\text { (5) }\end{array}$ & $\begin{array}{c}\text { GMM } \\
(6)\end{array}$ \\
\hline Proportion of beneficiaries & $\begin{array}{l}-0.2359 \\
(0.5610)\end{array}$ & $\begin{array}{l}-0.0932 \\
(0.3043)\end{array}$ & $\begin{array}{l}-0.1971 \\
(0.4015)\end{array}$ & $\begin{array}{l}-0.8286^{*} \\
(0.4226)\end{array}$ & $\begin{array}{l}-1.0153 \\
(1.7312)\end{array}$ \\
\hline Labour income (1/10) & $\begin{array}{l}1.7796^{\star \star \star} \\
(0.0907)\end{array}$ & $\begin{array}{l}2.0554^{\star \star \star} \\
(0.0511)\end{array}$ & $\begin{array}{l}2.2308^{\star \star \star} \\
(0.0930)\end{array}$ & $\begin{array}{l}1.2844^{\star \star \star} \\
(0.0860)\end{array}$ & $\begin{array}{l}1.3591^{\star \star \star} \\
(0.4421)\end{array}$ \\
\hline Non-labour income $(1 / 10)$ & $\begin{array}{l}-0.6066^{\star * \star} \\
(0.1355)\end{array}$ & $\begin{array}{l}-0.5466^{\star \star \star} \\
(0.0864)\end{array}$ & $\begin{array}{l}-0.4880^{\star * \star} \\
(0.0972)\end{array}$ & $\begin{array}{l}-0.0318 \\
(0.0964)\end{array}$ & $\begin{array}{l}-1.1543^{\star} \\
(0.6048)\end{array}$ \\
\hline Unemployment rate & $\begin{array}{c}-11.6967^{\star \star \star} \\
(1.0357)\end{array}$ & $\begin{array}{l}-9.3645^{\star \star *} \\
(0.7218)\end{array}$ & $\begin{array}{l}-7.9904^{\star \star *} \\
(0.7478)\end{array}$ & $\begin{array}{l}-3.9574^{\star \star *} \\
(0.8010)\end{array}$ & $\begin{array}{c}-14.2965^{\star \star \star} \\
(5.0715)\end{array}$ \\
\hline Proportion of children between $0-14$ & $\begin{array}{c}0.9797 \\
(1.9722)\end{array}$ & $\begin{array}{l}4.1298^{\star * \star} \\
(1.1460)\end{array}$ & $\begin{array}{l}5.3883^{\star * \star} \\
(1.4268)\end{array}$ & $\begin{array}{l}3.9187^{\star * \star} \\
(1.3168)\end{array}$ & $\begin{array}{c}2.2846 \\
(2.2126)\end{array}$ \\
\hline Age & $\begin{array}{l}1.0684^{\star \star \star} \\
(0.1717)\end{array}$ & $\begin{array}{l}0.5867^{\star \star \star} \\
(0.1058)\end{array}$ & $\begin{array}{l}0.4510^{\star * \star} \\
(0.1160)\end{array}$ & $\begin{array}{l}0.2745^{\star \star} \\
(0.1140)\end{array}$ & $\begin{array}{l}0.5995^{\star \star \star} \\
(0.1696)\end{array}$ \\
\hline Age square & $\begin{array}{l}-0.0127^{\star \star *} \\
(0.0019)\end{array}$ & $\begin{array}{l}-0.0076^{\star \star *} \\
(0.0012) \\
\text { Random }\end{array}$ & $\begin{array}{c}-0.0060^{\star * *} \\
(0.0013) \\
\text { Fixed }\end{array}$ & $\begin{array}{c}-0.0032^{\star \star} \\
(0.0013) \\
\text { First }\end{array}$ & $\begin{array}{l}-0.0067^{* * *} \\
(0.0024)\end{array}$ \\
\hline Schooling & $\begin{array}{l}1.9203^{\star * \star} \\
(0.5245)\end{array}$ & $\begin{array}{l}0.4189 \\
(0.2821)\end{array}$ & $\begin{array}{c}0.0061 \\
(0.4503)\end{array}$ & $\begin{array}{l}-1.3598^{\star *} \\
(0.5877)\end{array}$ & $\begin{array}{l}-0.4065 \\
(0.6940)\end{array}$ \\
\hline Schooling square & $\begin{array}{l}-0.1969^{\star * *} \\
(0.0484)\end{array}$ & $\begin{array}{l}-0.0731^{* * \star} \\
(0.0275)\end{array}$ & $\begin{array}{l}-0.0317 \\
(0.0423)\end{array}$ & $\begin{array}{l}0.1164^{* *} \\
(0.0557)\end{array}$ & $\begin{array}{c}0.0358 \\
(0.0695)\end{array}$ \\
\hline Proportion married & $\begin{array}{l}-7.9715^{\star \star \star} \\
(1.0388)\end{array}$ & $\begin{array}{l}-4.4348^{\star \star \star} \\
(0.6575)\end{array}$ & $\begin{array}{l}-3.3059^{\star \star \star} \\
(0.8067)\end{array}$ & $\begin{array}{l}-0.3785 \\
(0.7410)\end{array}$ & $\begin{array}{l}-6.7331^{\star \star *} \\
(1.8405)\end{array}$ \\
\hline Proportion of whites & $\begin{array}{l}-1.2109^{\star *} \\
(0.5789)\end{array}$ & $\begin{array}{l}-0.3970 \\
(0.4033)\end{array}$ & $\begin{array}{c}0.2897 \\
(0.4789)\end{array}$ & $\begin{array}{l}-0.2827 \\
(0.4838)\end{array}$ & $\begin{array}{l}-0.0106 \\
(0.7250)\end{array}$ \\
\hline Proportion of urban population & $\begin{array}{l}-1.6817^{\star *} \\
(0.7914)\end{array}$ & $\begin{array}{l}-3.0585^{\star \star \star} \\
(0.4893)\end{array}$ & $\begin{array}{l}-1.3986 \\
(0.9756)\end{array}$ & $\begin{array}{c}0.6730 \\
(0.8464)\end{array}$ & $\begin{array}{l}-1.5359 \\
(1.3863)\end{array}$ \\
\hline Proportion in administrative occupations & $\begin{array}{l}-9.7746^{\star \star \star} \\
(1.2427)\end{array}$ & $\begin{array}{l}-4.2795^{\star \star \star} \\
(0.9255)\end{array}$ & $\begin{array}{l}-2.5795^{\star \star \star} \\
(0.9756)\end{array}$ & $\begin{array}{c}0.0624 \\
(0.9279)\end{array}$ & $\begin{array}{c}1.9328 \\
(1.5897)\end{array}$ \\
\hline Proportion in service occupations & $\begin{array}{l}-5.0698^{* * *} \\
(0.5741)\end{array}$ & $\begin{array}{l}-1.2654^{\star \star \star} \\
(0.3762)\end{array}$ & $\begin{array}{c}0.0039 \\
(0.4425)\end{array}$ & $\begin{array}{c}0.2418 \\
(0.3984)\end{array}$ & $\begin{array}{c}0.8091 \\
(0.6367)\end{array}$ \\
\hline Proportion in commercial occupations & $\begin{array}{l}-4.8685^{\star * \star} \\
(0.8028) \\
\end{array}$ & $\begin{array}{l}-1.5492^{\star * \star} \\
(0.6006) \\
\end{array}$ & $\begin{array}{l}-0.4474 \\
(0.6592) \\
\end{array}$ & $\begin{array}{r}0.3100 \\
(0.6192) \\
\end{array}$ & $\begin{array}{r}1.5322 \\
(1.0069) \\
\end{array}$ \\
\hline F-test: & 82.58 & 2990.05 & 76.99 & 615.18 & 9.13 \\
\hline P-value & 0.0000 & 0.0000 & 0.0000 & 0.0000 & 0.0000 \\
\hline $\begin{array}{l}\text { Hausman test: } \chi^{2} \\
\text { P-value }\end{array}$ & & & $\begin{array}{l}188.41 \\
0.0000\end{array}$ & & \\
\hline $\begin{array}{l}\text { Hansen test: } \chi^{2} \\
\text { P-value }\end{array}$ & & & & & $\begin{array}{l}106.24 \\
0.0686\end{array}$ \\
\hline Number of observations & 4030 & 4030 & 4030 & 3224 & 2418 \\
\hline
\end{tabular}

Notes: See Table 9. The below-median sample refers to females whose family per capita income is below the median family per capita income of the municipalities they live in. 


\subsubsection{Males}

Table 11 presents the results for hours worked for the overall sample of males. Apart from OLS, all other models' estimates of the effect of interest are positive. However, only one estimate is statistically different from zero at conventional levels. Taking the average of all estimates (approximately 0.73 ), the elasticity [computed at the mean values of $(y, p)=(33.9,0.136)]$ is less than 0.01 . This implies that increases in the proportion of CCT beneficiaries in Brazil would have no (or negligible) effects on males' mean supply of hours.

Contrasting the estimates for the participation rate and for the mean supply of hours, there is a distinction as compared to the female case. There the former effect is basically nil, while the latter is negative; here the former effect is positive, while the latter is nil. Hence, in term of sign, it seems that the Brazilian CCT programmes do not change the labour supply of hours of males but increase their participation rate; in contrast they decrease the supply of hours of females without affecting their participation rate. In all cases, however, it should be pointed out that, if there are any effects at all, they are quite small in magnitude.

As in the case of all females, the signs of the effects of the other covariates are similar to those found for the participation rate. Again, a noticeable exception is the unemployment rate, whose effect on hours is negative.

Table 12 displays the results for the below-median sample of males. All five point estimates of the effect of interest are positive, but only one is significant on statistical grounds. The implied elasticity using the average of all estimates (approximately $1.43)$ and the mean values of $(y, p)=(31.9,0.194)$ is around 0.01 , implying that a $10 \%$ increase in the proportion of beneficiaries would rise the mean number of hours worked for this group of males in $0.1 \%$. As in the case for all males, the results indicate that the Brazilian CCTs increase the participation rate for this sample but have no (or negligible) effects on the their mean labour supply of hours. 
Table 11 - Effect of CCT Programmes on Hours Worked of Males: Overall Sample

\begin{tabular}{|c|c|c|c|c|c|}
\hline Covariates & $\begin{array}{l}\text { OLS } \\
(2)\end{array}$ & $\begin{array}{c}\text { Effects } \\
\text { (3) }\end{array}$ & $\begin{array}{l}\text { Effects } \\
\text { (4) }\end{array}$ & $\begin{array}{c}\text { Difference } \\
\text { (5) }\end{array}$ & $\begin{array}{l}\text { GMM } \\
(6)\end{array}$ \\
\hline Proportion of beneficiaries & $\begin{array}{l}-0.6309 \\
(0.6899)\end{array}$ & $\begin{array}{c}0.2766 \\
(0.5126)\end{array}$ & $\begin{array}{c}0.5778 \\
(0.6402)\end{array}$ & $\begin{array}{l}1.6025^{\star \star} \\
(0.6381)\end{array}$ & $\begin{array}{c}1.8281 \\
(2.1012)\end{array}$ \\
\hline Labour income (1/10) & $\begin{array}{l}0.0827^{\star * *} \\
(0.0078)\end{array}$ & $\begin{array}{l}0.0611^{* * *} \\
(0.0063)\end{array}$ & $\begin{array}{l}0.0563^{\star \star \star} \\
(0.0061)\end{array}$ & $\begin{array}{l}0.0473^{* * *} \\
(0.0066)\end{array}$ & $\begin{array}{c}0.0457 \\
(0.0302)\end{array}$ \\
\hline Non-labour income $(1 / 10)$ & $\begin{array}{l}-0.0932^{\star \star *} \\
(0.0145)\end{array}$ & $\begin{array}{l}-0.0879^{\star * *} \\
(0.0129)\end{array}$ & $\begin{array}{l}-0.0481^{* * *} \\
(0.0130)\end{array}$ & $\begin{array}{l}-0.0229 \\
(0.0141)\end{array}$ & $\begin{array}{l}-0.0728 \\
(0.0806)\end{array}$ \\
\hline Unemployment rate & $\begin{array}{c}-27.7628^{\star * \star} \\
(1.6085)\end{array}$ & $\begin{array}{c}-24.5796^{* \star *} \\
(1.2719)\end{array}$ & $\begin{array}{c}-19.7568^{\star * *} \\
(1.3293)\end{array}$ & $\begin{array}{l}-9.7300^{* * *} \\
(1.4121)\end{array}$ & $\begin{array}{c}-30.4398^{* * \star} \\
(7.7795)\end{array}$ \\
\hline Proportion of children between $0-14$ & $\begin{array}{l}-1.6475 \\
(2.3585)\end{array}$ & $\begin{array}{c}0.6947 \\
(1.7397)\end{array}$ & $\begin{array}{c}4.9978^{\star *} \\
(1.9476)\end{array}$ & $\begin{array}{c}0.3146 \\
(1.8773)\end{array}$ & $\begin{array}{c}1.8819 \\
(3.2170)\end{array}$ \\
\hline Age & $\begin{array}{l}1.9424^{\star \star \star} \\
(0.1839)\end{array}$ & $\begin{array}{l}1.7164^{\star \star \star} \\
(0.1423)\end{array}$ & $\begin{array}{l}1.6313^{\star \star \star} \\
(0.1617)\end{array}$ & $\begin{array}{l}0.7985^{\star \star \star} \\
(0.1547)\end{array}$ & $\begin{array}{l}1.7843^{\star \star \star} \\
(0.2353)\end{array}$ \\
\hline Age square & $\begin{array}{l}-0.0246^{\star \star \star} \\
(0.0020)\end{array}$ & $\begin{array}{l}-0.0219^{\star \star *} \\
(0.0015)\end{array}$ & $\begin{array}{l}-0.0208^{\star \star \star} \\
(0.0018)\end{array}$ & $\begin{array}{l}-0.0105^{\star \star \star} \\
(0.0017)\end{array}$ & $\begin{array}{l}-0.0217^{\star \star \star} \\
(0.0026)\end{array}$ \\
\hline Schooling & $\begin{array}{l}0.9259^{\star *} \\
(0.4092)\end{array}$ & $\begin{array}{c}0.4320 \\
(0.3101)\end{array}$ & $\begin{array}{l}-0.6429^{*} \\
(0.3641)\end{array}$ & $\begin{array}{l}2.4243^{\star * *} \\
(0.6685)\end{array}$ & $\begin{array}{l}-0.8057 \\
(0.5156)\end{array}$ \\
\hline Schooling square & $\begin{array}{l}-0.1620^{* \star \star} \\
(0.0319)\end{array}$ & $\begin{array}{l}-0.0817^{\star * *} \\
(0.0247)\end{array}$ & $\begin{array}{l}0.0599^{* *} \\
(0.0296)\end{array}$ & $\begin{array}{l}-0.2161^{* * *} \\
(0.0540)\end{array}$ & $\begin{array}{r}0.0826^{*} \\
(0.0451)\end{array}$ \\
\hline Proportion married & $\begin{array}{l}8.8246^{* * *} \\
(1.4599)\end{array}$ & $\begin{array}{l}7.6752^{* \star *} \\
(1.1112)\end{array}$ & $\begin{array}{l}5.5037^{\star * *} \\
(1.2113)\end{array}$ & $\begin{array}{l}3.4944^{\star * *} \\
(1.1591)\end{array}$ & $\begin{array}{l}5.3435^{* * *} \\
(1.7212)\end{array}$ \\
\hline Proportion of whites & $\begin{array}{l}-0.6144 \\
(0.6248)\end{array}$ & $\begin{array}{l}-0.3354 \\
(0.5302)\end{array}$ & $\begin{array}{l}-1.4747^{\star *} \\
(0.6768)\end{array}$ & $\begin{array}{c}0.6491 \\
(0.7562)\end{array}$ & $\begin{array}{c}1.2221 \\
(0.9646)\end{array}$ \\
\hline Proportion of urban population & $\begin{array}{l}-2.6690^{\star \star *} \\
(0.6542)\end{array}$ & $\begin{array}{l}-4.0697^{\star * *} \\
(0.6137)\end{array}$ & $\begin{array}{l}-5.3394^{* * *} \\
(1.3309)\end{array}$ & $\begin{array}{l}1.3547 \\
(1.4253)\end{array}$ & $\begin{array}{l}-4.6355^{\star *} \\
(1.8585)\end{array}$ \\
\hline Proportion in administrative occupations & $\begin{array}{l}-6.9284^{* \star *} \\
(2.1265)\end{array}$ & $\begin{array}{l}-5.1490^{\star * *} \\
(1.7767)\end{array}$ & $\begin{array}{l}-3.8760^{* *} \\
(1.8579)\end{array}$ & $\begin{array}{l}-0.2570 \\
(1.9048)\end{array}$ & $\begin{array}{l}-3.1583 \\
(2.7311)\end{array}$ \\
\hline Proportion in service occupations & $\begin{array}{l}-3.1937^{\star \star} \\
(1.2785)\end{array}$ & $\begin{array}{l}-1.3307 \\
(1.0607)\end{array}$ & $\begin{array}{r}2.0506^{*} \\
(1.1958)\end{array}$ & $\begin{array}{l}-6.9829^{\star \star \star} \\
(1.4229)\end{array}$ & $\begin{array}{c}0.0742 \\
(1.7723)\end{array}$ \\
\hline Proportion in commercial occupations & $\begin{array}{l}-5.7593^{\star * *} \\
(1.6566)\end{array}$ & $\begin{array}{l}-2.8844^{\star *} \\
(1.3667) \\
\end{array}$ & $\begin{array}{c}-0.4422 \\
(1.3226) \\
\end{array}$ & $\begin{array}{l}-0.4121 \\
(1.3163)\end{array}$ & $\begin{array}{l}-1.3148 \\
(2.0391) \\
\end{array}$ \\
\hline F-test: & 119.35 & $\begin{array}{r}194570.28 \\
\text { Random }\end{array}$ & $\begin{array}{l}57.08 \\
\text { Fixed }\end{array}$ & $\begin{array}{c}2059.64 \\
\text { First }\end{array}$ & 19.27 \\
\hline P-value & 0.0000 & 0.0000 & 0.0000 & 0.0000 & 0.0000 \\
\hline $\begin{array}{l}\text { Hausman test: } \chi^{2} \\
\text { P-value }\end{array}$ & & & $\begin{array}{l}164.97 \\
0.0000\end{array}$ & & \\
\hline Hansen test: $\chi^{2}$ & & & & & 93.74 \\
\hline P-value & & & & & 0.2665 \\
\hline Number of observations & 4030 & 4030 & 4030 & 3224 & 2418 \\
\hline
\end{tabular}

Notes: See Table 9. 
Table 12 - Effect of CCT Programmes on Hours Worked of Males: Below-Median Sample

\begin{tabular}{|c|c|c|c|c|c|}
\hline Covariates & $\begin{array}{l}\text { OLS } \\
(2) \\
\end{array}$ & $\begin{array}{c}\text { Effects } \\
(3)\end{array}$ & $\begin{array}{c}\text { Effects } \\
\text { (4) }\end{array}$ & $\begin{array}{c}\text { Difference } \\
(5)\end{array}$ & $\begin{array}{c}\text { GMM } \\
(6)\end{array}$ \\
\hline Proportion of beneficiaries & $\begin{array}{c}0.1889 \\
(0.6241)\end{array}$ & $\begin{array}{c}0.5721 \\
(0.3626)\end{array}$ & $\begin{array}{c}0.4952 \\
(0.5378)\end{array}$ & $\begin{array}{l}1.9569^{\star \star \star} \\
(0.6033)\end{array}$ & $\begin{array}{c}3.9159 \\
(3.0073)\end{array}$ \\
\hline Labour income (1/10) & $\begin{array}{c}0.7198^{\star \star \star} \\
(0.0464)\end{array}$ & $\begin{array}{c}0.7960^{\star \star \star} \\
(0.0333)\end{array}$ & $\begin{array}{c}0.9192^{\star * \star} \\
(0.0504)\end{array}$ & $\begin{array}{c}0.6193^{* * *} \\
(0.0465)\end{array}$ & $\begin{array}{l}0.5107^{\star} \\
(0.2670)\end{array}$ \\
\hline Non-labour income $(1 / 10)$ & $\begin{array}{c}-1.4850^{\star \star \star} \\
(0.1342)\end{array}$ & $\begin{array}{c}-1.2628^{\star \star *} \\
(0.0916)\end{array}$ & $\begin{array}{c}-1.0316^{\star \star \star} \\
(0.1161)\end{array}$ & $\begin{array}{c}-0.5550^{\star \star \star} \\
(0.1078)\end{array}$ & $\begin{array}{c}-1.5068^{\star \star} \\
(0.6385)\end{array}$ \\
\hline Unemployment rate & $\begin{array}{c}-23.7888^{\star * *} \\
(1.1812)\end{array}$ & $\begin{array}{c}-19.2739^{* * *} \\
(0.8785)\end{array}$ & $\begin{array}{c}-16.1634^{\star \star *} \\
(1.0346)\end{array}$ & $\begin{array}{c}-7.2695^{\star * *} \\
(1.0580)\end{array}$ & $\begin{array}{c}-25.0366^{\star \star \star} \\
(7.1113)\end{array}$ \\
\hline Proportion of children between $0-14$ & $\begin{array}{c}2.2966 \\
(2.1057)\end{array}$ & $\begin{array}{l}7.3479^{\star \star *} \\
(1.4950)\end{array}$ & $\begin{array}{c}10.9509^{\star \star \star} \\
(1.8815)\end{array}$ & $\begin{array}{l}3.5647^{\star *} \\
(1.7471)\end{array}$ & $\begin{array}{c}2.4448 \\
(10.5554)\end{array}$ \\
\hline Age & $\begin{array}{c}1.0450^{\star \star \star} \\
(0.1660)\end{array}$ & $\begin{array}{c}0.8368^{\star \star \star} \\
(0.1273)\end{array}$ & $\begin{array}{c}0.7720^{\star * \star} \\
(0.1516)\end{array}$ & $\begin{array}{c}0.5959^{\star \star *} \\
(0.1310)\end{array}$ & $\begin{array}{c}0.8997 \\
(1.0601)\end{array}$ \\
\hline Age square & $\begin{array}{c}-0.0120^{\star * *} \\
(0.0019)\end{array}$ & $\begin{array}{c}-0.0104^{\star * *} \\
(0.0015)\end{array}$ & $\begin{array}{c}-0.0100^{\star * *} \\
(0.0017)\end{array}$ & $\begin{array}{c}-0.0073^{\star * *} \\
(0.0015)\end{array}$ & $\begin{array}{l}-0.0130 \\
(0.0125)\end{array}$ \\
\hline Schooling & $\begin{array}{c}0.1290 \\
(0.4372)\end{array}$ & $\begin{array}{l}-0.2306 \\
(0.2622)\end{array}$ & $\begin{array}{l}-0.5773 \\
(0.4201)\end{array}$ & $\begin{array}{c}2.8554^{\star * \star} \\
(0.5969)\end{array}$ & $\begin{array}{l}-3.9238^{\star *} \\
(1.6795)\end{array}$ \\
\hline Schooling square & $\begin{array}{l}-0.0775^{\star} \\
(0.0403)\end{array}$ & $\begin{array}{l}-0.0269 \\
(0.0257)\end{array}$ & $\begin{array}{c}0.0336 \\
(0.0390)\end{array}$ & $\begin{array}{c}-0.3153^{\star * *} \\
(0.0584)\end{array}$ & $\begin{array}{l}0.3835^{* *} \\
(0.1533)\end{array}$ \\
\hline Proportion married & $\begin{array}{c}9.1814^{\star \star \star} \\
(1.1707)\end{array}$ & $\begin{array}{c}8.4658^{\star \star \star *} \\
(0.9111)\end{array}$ & $\begin{array}{c}7.6056^{\star \star \star} \\
(1.1098)\end{array}$ & $\begin{array}{l}3.6438^{\star \star \star} \\
(1.0218)\end{array}$ & $\begin{array}{c}6.6646 \\
(6.6278)\end{array}$ \\
\hline Proportion of whites & $\begin{array}{c}-1.9426^{\star \star \star} \\
(0.6133)\end{array}$ & $\begin{array}{c}-1.5269^{* \star \star} \\
(0.4695)\end{array}$ & $\begin{array}{l}-0.9816 \\
(0.6410)\end{array}$ & $\begin{array}{l}-0.0553 \\
(0.6762)\end{array}$ & $\begin{array}{c}2.4732 \\
(4.7626)\end{array}$ \\
\hline Proportion of urban population & $\begin{array}{c}-3.7431^{\star * \star} \\
(0.6359)\end{array}$ & $\begin{array}{c}-5.4487^{\star \star \star} \\
(0.4724)\end{array}$ & $\begin{array}{c}-6.5568^{\star \star \star} \\
(0.9724)\end{array}$ & $\begin{array}{l}-0.3385 \\
(0.8717)\end{array}$ & $\begin{array}{l}-4.0523 \\
(8.4539)\end{array}$ \\
\hline Proportion in administrative occupations & $\begin{array}{c}-8.5585^{\star * \star} \\
(1.9003)\end{array}$ & $\begin{array}{c}-5.6829^{\star \star \star} \\
(1.6951)\end{array}$ & $\begin{array}{c}-3.5420^{\star *} \\
(1.7826)\end{array}$ & $\begin{array}{l}-3.0668^{*} \\
(1.6932)\end{array}$ & $\begin{array}{c}3.5352 \\
(15.5984)\end{array}$ \\
\hline Proportion in service occupations & $\begin{array}{l}-1.2544 \\
(0.9113)\end{array}$ & $\begin{array}{c}0.1267 \\
(0.7978)\end{array}$ & $\begin{array}{c}1.2425 \\
(0.9254)\end{array}$ & $\begin{array}{l}-6.0490^{* * *} \\
(1.0356)\end{array}$ & $\begin{array}{l}1.1845 \\
(8.5430)\end{array}$ \\
\hline Proportion in commercial occupations & $\begin{array}{c}-5.0585^{\star * *} \\
(1.3133)\end{array}$ & $\begin{array}{c}-3.1426^{\star * *} \\
(1.0440)\end{array}$ & $\begin{array}{l}-1.7711 \\
(1.2104)\end{array}$ & $\begin{array}{l}-1.2735 \\
(1.1060)\end{array}$ & $\begin{array}{r}-11.0825 \\
(9.0792)\end{array}$ \\
\hline F-test: & 126.64 & 3939.71 & 98.42 & 1252.43 & 3.05 \\
\hline P-value & 0.0000 & 0.0000 & 0.0000 & 0.0000 & 0.0000 \\
\hline $\begin{array}{l}\text { Hausman test: } \chi^{2} \\
\text { P-value }\end{array}$ & & & $\begin{array}{l}112.01 \\
0.0000\end{array}$ & & \\
\hline & & Random & Fixed & First & \\
\hline Hansen test: $\chi^{2}$ & & & & & 96.17 \\
\hline P-value & & & & & 0.0504 \\
\hline Number of observations & 4030 & 4030 & 4030 & 3224 & 2418 \\
\hline
\end{tabular}

Notes: See Table 9. The below-median sample refers to males whose family per capita income is below the median family per capita income of the municipalities they live in. 
Overall, the effects of the other covariates are similar to those obtained for all males. Main exceptions are the impacts of labour and non-labour income, which are higher in absolute terms.

\section{Conclusions}

In this paper, we estimated the effects of the Brazilian CCT programmes on the labour supply of adults. These effects were estimated from a time-series-crosssection sample of municipalities in the country. We constructed this data set from the Pesquisa Nacional por Amostra de Domicílios - PNAD, which is a national household survey that is fielded annually in the same set of municipalities between census years (only households are randomly sampled across years). The outcome variables were the participation rate and the average number of hours worked at the municipal level. Since PNAD does not ask direct questions about CCT programme participation, we constructed an indirect measure of programme assignment that was based on the typical values of the programmes' transfers to beneficiary households. Results are obtained separately for all males and females and, in order to investigate whether the effects of interest differ for poorer individuals, we also obtained results for males and females that live in families whose per capita income falls below the median per capita family income of the municipalities they live in. Methodologically, we employ various linear panel data models typically used in this literature.

Our results indicate that the impact of the Brazilian CCT programmes on the female participation rate is not significant either on statistical grounds or in terms of magnitude. This is observed for all females and for those below the median income. As for males, there is evidence that the effect on the participation rate is positive, though very small in magnitude. Again, this is observed for all males and for those below the median income. In terms of the supply of hours, the results indicate a small negative effect on all females but an insignificant impact on those that live below the median income. For both groups of males, the results show insignificant impacts of the programmes both in size and on statistical grounds.

In sum, our results do not show significant effects of the Brazilian CCT programmes on either the labour market participation or the supply of hours of men and women. Rather, our results seem to be compatible with a story that CCT programmes do not affect the labour supply of adult males and females. In fact, this contention seems to be in line with the empirical literature that uses individual data and compare treatment and control groups' outcomes. 


\section{References}

ARELLANO, M.; BOND, S. R. Some tests of specification for panel data: Monte Carlo evidence and an application to employment equations. Review of Economic Studies, 58, p. 277-297, 1991.

BARROS, R. P.; CARVALHO, M.; S. FRANCO, S. O papel das transferências públicas na queda recente da desigualdade de renda brasileira. In: BARROS, R. P. de; FOGUEL, M. N.; ULYSSEA, G. (Eds.). Desigualdade de renda no Brasil: uma análise da queda recente. Brasília: Instituto de Pesquisa Econômica Aplicada, 2007. v. 2, p. 41-86.

BLUNDELL, R.; MACURDY, T. Labor supply: a review of alternative approaches. In: ASHENFELTER, O.; CARD, D. (Ed.). Handbook of labor economics. Amsterdam, The Netherlands, 1999. v. 3, p. 1559-1695.

CEDEPLAR. Projeto de avaliação do impacto do Bolsa Família - Relatório analítico final. CEDEPLAR, 2006. Mimeo.

DEATON, A. Panel data from time serie of cross-sections. Journal of Econometrics, 30, p. 109-126, 1985.

FERRO, A. R.; NICOLLELA, A. C. The impact of conditional cash transfer programs on household work decisions in Brazil. São Paulo: Universidade de São Paulo, 2007. Mimeo.

FULLER, W. A. Measurement error models. Wiley series in probability and statistics. USA: John Wiley and Sons, 1987.

HANDA, S.; DAVIS, B. The experience of conditional cash transfers in Latin America and the Caribbean. Development Policy Review, 24, p. 513-536, 2006.

KILLINGSWORTH, M. R. Labor supply. Cambridge: Cambridge University Press, 1983.

MEDEIROS, M.; BRITTO, T.; SOARES, F. Programas focalizados de transferência de renda no Brasil: contribuições para o debate. Brasília: Instituto de Pesquisa Econômica Aplicada, 2007. (Texto para Discussão, 1283).

PARKER, S. W.; SKOUFIAS, E. The impact of Progresa on work, leisure, and time allocation. International Food Policy Research Institute, 2000. (Final report)

RAVALLION, M.; WODON, Q. Does child labor displace schooling? Economic Journal, v.110, p. C158-C175, 2000.

RAWLINGS, L. B.; RUBIO, G. M. Evaluating the impact of conditional cash transfer programs. World Bank, Policy Research, 2003. (Working Paper 3119).

. Evaluating the impact of conditional cash transfer programs. World Bank Research Observer, 20, p. 29-55, 2005.

REIS, M. C.; CAMARGO, J. M. Impactos da aposentadoria e pensões sobre a educação e participação dos jovens na força de trabalho. Pesquisa e Planejamento Econômico, 37, p. 221-246, 2007. 
SILVA, P. L. N.; PESSOA, D. G. C.; LILA, M. F. Análise estatística de dados da PNAD: incorporando a estrutura do plano amostral. Ciência e Saúde Coletiva, 7, p. 659-670, 2002.

SOARES, F.; SOARES, S.; MEDEIROS, M.; OSÓRIO, R. Programas de transferência de renda no Brasil: impactos sobre a desigualdade. In: BARROS, R. P. de; FOGUEL, M. N.; ULYSSEA, G. (Ed.). Desigualdade de renda no Brasil: uma análise da queda recente. Instituto de Pesquisa Econômica Aplicada, 2008. v. 2, cap. 17, p. 87-129.

SOARES, S.; OSÓRIO, R.; SOARES, F.; MEDEIROS, M.; ZEPEDA, E. Conditional cash transfers in Brazil, Chile and Mexico: impacts upon inequality. International Poverty Center, 2007. (Working Paper 35).

TAVARES, P. A. Efeito do programa bolsa família sobre a oferta de trabalho das mães. In: ENCONTRO NACIONAL DE ECONOMIA, 36, 2008, Salvador. Anais... ANPEC, 2008.

WINDMEIJER, F. A finite sample correction for the variance of linear efficient twostep GMM estimators. Journal of Econometrics, 126, p. 25-51, 2005. 